\title{
長期載荷を受ける鉄筋集成材梁のクリープ特性に関する研究 CREEP BEHAVIOR OF HYBRID REBAR-GLULAM TIMBER BEAM UNDER LONG-TERM LOADING
}

\author{
塩屋 晋一*1, 福留 幹 太2 $^{* 2}$, 松岡 直 ${ }^{* 3}$
}

\section{Shinichi SHIOYA, Kanta FUKUDOME and Nao MATSUOKA}

\begin{abstract}
Creep behavior of hybrid glulam timber beams with a small size under 4-year term loading is reported and the followings are clarified:

1. Creep of curvature of the hybrid beam rapidly boosted against prediction based on assumption of Navier hypothesis, in same term every year when humidity increases in Japan, i.e., July-September.

2. The boost results from position of rebar-embedded lamina in beam section.

3. The phenomenon may occur in the small- sized beams, however, real-full-sized beam can readily prevent it in several ways.

4. The waterproofed hybrid beam can significantly suppress its bending creep by rebars.
\end{abstract}

Keywords : Hybrid, Creep, Glulam timber, Steel deformed bar,Beam, Relative creep coefficient ハイブリッド, クリープ, 集成材, 異形鉄筋, 梁, クリープ係数

\section{1. はじめに}

異種材料を複合することにより，これまでに無い優れた性能を発 揮する柱や梁などの木質ハイブリッド軸材の研究が国外で活発にな ってきている。塩屋は Fig.1 右のように鉄筋を集成材内の曲げ縁に 接着して曲げ剛性と曲げ耐力を増大させる鉄筋集成材と，そのラー メン構法を開発している ${ }^{1)}$ 。鉄筋集成材は部材重量に対する曲げ剛 性の比が極めて高いため, 同図のようなロングスパンを実現できる。 同試作棟は柱と梁および小梁に鉄筋集成材を用いて，二方向ラーメ ンとして設計されている。

既に梁を対象にして繰り返しの曲げ荷重を受ける曲げ特性 ${ }^{2)}$, 曲 げ荷重を受ける曲げ特性の評価式 ${ }^{3)}$ ，曲代耐力に対する荷重継続期 間の影響係数 ${ }^{4)}$, 温度と含水率が変動する場合の鉄筋集成材内部の 応力の評価式 ${ }^{5}$, 繰り返しの水平加力を受ける鉄筋集成材柱の弾塑 性性状 ${ }^{6)}$ などを報告している。

木材は曲げヤング係数が小さいため，殆どの梁の設計では，たわ み制限により梁断面の寸法が決定する。木材の梁は長期載荷下では クリープたわみが生じ，それは断面寸法に大きく影響を与える。鉄 筋集成材の梁も同様で，そのクリープたわみの評価も重要になる。

塩屋は鉄筋量を大きくして梁の曲げ剛性を, 一般の集成材に比心゙ て 4.0-5.0 倍に増大させ，これにより集成材の使用量を減らして製 造費を，曲げ剛性が同じであれば，一般の集成材より安くすること

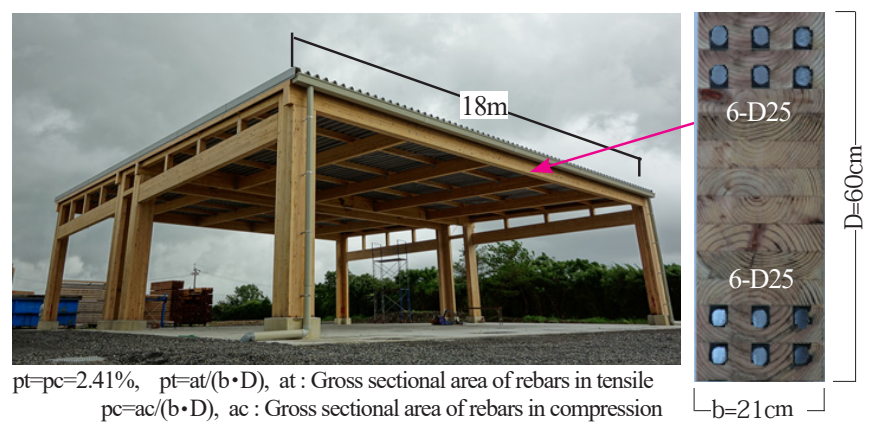

Fig. 1 Prototype building utilizing the hybrid beam and colum proposed in this study, designed by S. Shioya with appproval from authorities and constructed in July 2014

を目指している ${ }^{3)}$ 。当然，梁せいを $55-60 \%$ に縮減できる効果は建 築設計では自由度を増し，更に階高を抑制でき，建設費の抑制に大 きく貢献する。鉄筋量は梁断面に対する引張鉄筋比 $\mathrm{pt}$ と圧縮鉄筋 比 $\mathrm{pc}$ は等量で，それぞれ 2.0-3.0\%を想定している。これは，鉄筋 コンクリート造の梁では見られない高配筋である。

鉄筋集成材ではクリープたわみを、曲げ変形成分（曲率成分）の クリープ ( 以後，曲げクリープ ) とせん断変形成分のクリープ（以 後，せん断クリープ）に分けて評価する必要があるが、集成材のク リープはデータが蓄積されており、設計で用いる 50 年後のクリー
鹿児島大学大学院理工学研究科 教授 ·博士 (工学) (侏竹中工務店 修士 (工学)

鹿児島大学大学院理工学研究科建築学専攻 博士前期課程
Prof., Kagoshima University, Dr.Eng.

Takenaka Corporation, M.E.

Graduate School, Kagoshima University, Master Course Student 
プ調整係数も整備されている主1)。鉄筋による梁の曲げクリープを 抑制する機構が明らかになると, 鉄筋集成材梁のクリープ調整係数 の評価式も構築でき，そのクリープ抑制効果を利用する設計も可能 になる。特に高配筋の梁は，その効果が大きく期待される。

本研究は鉄筋集成材の断面寸法や配筋量を考慮できるクリープ調 整係数の評価式または評価方法を構築することを目的としている。

まず，高配筋の鉄筋集成材梁のクリープを調べるために室内（鹿 児島市内）で梁の長期載荷試験（試験 I）を行っている。現在，載 荷開始から約 4 年間が経過している。しかし，鉄筋集成材梁で曲率 が予想より急増する現象が毎年, 湿度が増加する時期に生じている。 集成材の吸湿と脱湿が影響を与えていると考え，そのメカニズムを 明らかにするために集成材の表面をコーティングした追加の長期載 荷試験（試験 II ）を実施している。これらの実験結果と, 既往の解 析結果および既に行った強制加湿による鉄筋集成材梁の長期載荷試 験結果を引用し，集成材のラミナ構成における，鉄筋を接着してい るラミナ ( 以後, 鉄筋ラミナ) 位置が原因であることを推論した。

本論文では，既往の研究と本研究の焦点，鉄筋集成材の曲げクリ ープ係数の評価方法，試験 I と試験 II，およびラミナ構成の問題点 と対策について述べる。更に試験 I と試験 II のデータから推定され る 50 年後のクリープ調整係数を示して，設計での対応の考え方に ついて述べる。またクリープ進行中のたわみ剛性（曲げ変形とせん 断変形を含む剛性）は弾性剛性とほぼ同じでクリープ進行中に心配 されるたわみの振動障害が生じる可能性が小さいことを述べる。

\section{2. 木質ハイブリッド部材のクリープに関する研究と本研究の焦点}

鉄筋を木材の梁に接着して補強する研究は Gramholm ${ }^{7)}$ の研究に はじまり, その後, 欧米の研究者により検討され, 強化プラッステ イク (FRP) などを補強材とする研究が行われた。初期の研究では 短期載荷の剛性や曲げ耐力を明らかにすることが主であり，これら に関する既往の研究は文献 3) で紹介しているので，そちらを参照 されたい。ここでは, 本論文の主題の長期載荷時のクリープに対す る補強材の効果を明らかにした既往の研究について述べる。

N.Plevris(1995) ら ${ }^{8)}$ が炭素繊維強化プラスティク (CFRP) 板 (幅 $: 45 \mathrm{~mm}$, 厚さ : 1.0-1.3mm, 以後 $45 \times 1.0-1.3$ と表現 ) を曲げ引張縁（以 後, 引張縁) のみに接着した木梁（梁幅: $45 \mathrm{~mm}$, 梁せい: $86 \mathrm{~mm}$, 以 後 $45 \times 86$ と表記 ）に対して恒温・恒湿環境で長期載荷を行い，クリ ープたわみの抑制効果を明らかにし，鉄筋コンクリート梁のクリー プ理論を適用し，その可能性を報告している。比較用試験体と補強 試験体の初期の木部の曲げ応力度を同じ值に設定していないことが 問題である。

W.G.Davids(2000) ら ${ }^{9}$ は，ガラス繊維強化プラスティク (GFRP) 板 $(38 \times 3.2-9.6)$ を引張縁のみに接着した集成材梁 $(130 \times 305)$ に対し て，一定の範囲の室内環境で長期載荷を行い，クリープたわみの抑 制効果と, クリープたわみの計算を報告している。その計算では, まず, 木材のクリープを評価し, 補強板の抑制効果を加算している。 この研究でも, 前述の木部の曲げ応力度を同じ值に設定していない。

J.R.Gilfillan(2003) ら ${ }^{10)}$ は炭素繊維強化プラスティク (CFRP) 板 $(68 \times 3.25$ 相当）を引張縁のみに接着した木梁（断面: $68 \times 120 ）$ に文 して温湿度が制御されていない室内で長期載荷 (2 年間)を行い, 補強によりクリープたわみが約 $50 \%$ に抑制されたと報告している。
R. Kliger(2008) ら ${ }^{11)}$ は鋼板 $(50 \times 2$ 相当 $)$ または CFRP 板 $(50 \times 1.4$ 相当）を引張縁のみに接着する木梁（70×45）に対して長期載荷を行 い，乾湿繰返しの室内環境においてメカノソープティブ $(\mathrm{MS})$ クリ 一プが大きくなることと，そのメカニズムを報告している。MS ク リープを抑制するためには圧縮縁と引張縁の両側に補強材を接着寸 ることが重要であると指摘している。また現代の接着剤の性能の向 上により鋼材と木部の剥離の問題を解決でき, 鋼材の利点を示唆し ている。

Yahyaei-Moayyed (2011) ら ${ }^{12)}$ はアラミド繊維強化プラスティク板 を梁の引張縁だけに接着する梁 $(38 \times 38)$ で，クリープの抑制効果の 可能性を報告している。

Conan らは，玄武岩を原材料とする繊維の強化プラスティク棒 (2-16 $\phi)$ を梁の下端の引張縁のみにU 溝を加工して接着した集成 材梁 $(96 \times 125)$ に対して長期載荷を行い，恒温恒湿の室内 (52 週間) における粘弾性クリープ $(2016)^{13)}$ と，繰り返しの強制加湿による MS クリープに対する抑制効果 $(2018)^{14)}$ を報告している。

国内では, 徳田 (1997) ら ${ }^{15)}$ が，引張縁と圧縮に LVL と異形鉄筋 （2-D10）を補強材として接着した木梁 $(90 \times 254)$ に対して温湿度が 制御されていない室内で長期載荷（約 1 年間）を行ったが，補強 材のクリープの抑制効果を確認するまでに至っていない。また中 島 (2004) ら ${ }^{16)}$ も，鋼板を補強材として，上下の曲げ縁にラグスク リューボルトにより固定または CFRP シートを接着した集成材梁 （100×200）に対して恒温恒湿の室内で長期載荷（400 日間）を行っ ているが，無補強梁も含めてクリープたわみがあまり進行しなかっ たため補強材のクリープの抑制効果を確認寸るまでに至っていない。

荒武 (2011) ら ${ }^{17}$ ) は片側または両側の曲げ縁に樹種やヤング係数 の異なるラミナを接着した集成材梁 $(105 \times 210)$ に対して温湿度が制 御されていない室内で長期載荷 (4 年間) を行い, MS クリープの 特性を明らかにして 50 年後のクリープ係数を予測するための適切 な測定期間を提案している。

海外の研究によると，補強材による梁のクリープの抑制効果は明 かである。また MS クリープを抑制するためには引張縁と圧縮縁の 両側を補強する必要がある。クリープたわみの評価は，木材の基礎 特性に基づく評価理論はまだ構築されておらず，それに鉄筋の効果 を考慮する方法の開発には時間を要する。

一方，設計での木梁のクリープたわみは，使用環境を考慮して， 工学的に安全側で 50 年後のクリープ調整係数を設定して評価する。 鉄筋集成材の梁のクリープ調整係数も，その集成材のクリープ調 整係数に鉄筋の効果を加算する方法が，現時点では実用的である。 Parada(2018) ら ${ }^{18)}$ も，薄肉 C 形折り鋼梁と幅が薄い木梁をボルトで 合成した補強梁のクリープ係数を，鋼梁のたわみ剛性と，クリープ を考慮した木梁のたわみ剛性を加算する方法を提案している。

本研究の目的は，鉄筋集成材の曲げクリープ調整係数の評価式ま たは方法を開発することである。鉄筋の梁の曲げ剛性への寄与効果 は断面に平面保持を仮定して評価することが先ず考えられる。同仮 定の妥当性はウェッブに相当する木材のせん断弾性係数の大きさに 左右される。木材のせん断弾性係数は曲げヤング係数の $1 / 15$ とさ れ，コンクリートや鋼材に比べると極めて小さい。しかし，既往の 短期載荷の研究では同仮定を用いて精度よく曲げ剛性を評価でき, 内部の鉄筋のひずみも精度よく評価できることを報告している ${ }^{2,3)}$ 


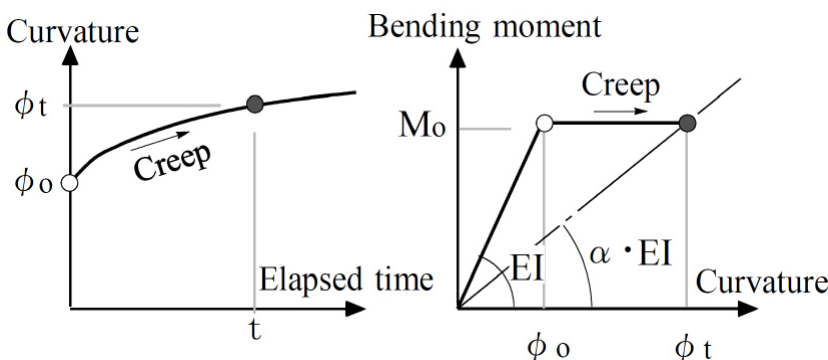

Fig. 2 Schematizing curvature-time relationship and bending moment-curvature relationship during

一方，長期載荷の状態でクリープが進行すると，その仮定の妥 当性が崩れることも心配される。比良 (2012) ら ${ }^{19)}$ は鉄筋集成材梁 (140×240) に対して強制加湿の室内で長期載荷（90日間）を行い, 集成材のクリープを増大させて鉄筋のクリープの抑制効果を明らか にして，平面保持の仮定を用いてその曲げクリープの抑制効果を評 価できることを報告し,曲げクリープ係数の評価式も提案している。 しかし, 同試験体は引張鉄筋と圧縮鉄筋は等量で，それらの鉄筋比 pt は $1.38 \%$ で, 短期載荷時の曲げ剛性の増加率は 1.63 であった。

現在，鉄筋集成材の鉄筋比 pt は 2.0-4.0\% で短期載荷時の曲げ剛 性の増加率は 4.0-5.0 を想定している。この様な高配筋でも，同様 に平面保持の仮定に基づく曲げのクリープ係数の評価式が適用でき るかが，本論文の焦点である。前述の N. Plevris ら ${ }^{8)}$ や W. G. Davids ら 9)の評価方法も，平面保持の仮定に基づいている。

3. 鉄筋集成材梁のクリープ係数の評価式と平面保持の仮定の崩れ

Fig. 2 に長期載荷によるモーメントを受けている梁の曲率の経時 変化とモーメントー曲率関係を模式的に示す。 $\phi_{0}$ は長期載荷開始 時の曲率で， $\phi \mathrm{t}$ は経過時間 $\mathrm{t}$ 時の曲率である。曲率の相対クリー プの係数 $\mathrm{C}_{\phi}$ は $\phi_{\mathrm{t}} / \phi_{0}$ と表される。以後, 曲率のクリープ係数と定 義する。 $\mathrm{t}$ 時の $\phi \mathrm{t}$ は，曲げ剛性 EI が低下したものとしても評価で きる。その低下率 $\alpha$ は $\mathrm{C}_{\phi}$ の逆数となる。

弾性の曲げ剛性 EI は平面保持の仮定に基づき集成材の弾性の曲 げ剛性 $\mathrm{EI}_{\mathrm{w}}$ と鉄筋が寄与する弾性の曲げ剛性 $\mathrm{EI}_{\mathrm{S}}$ の和で評価できる

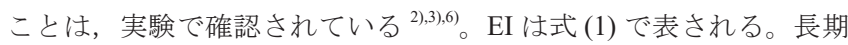
載荷時のモーメントを $\mathrm{M}_{0}$ とすると, 長期載荷開始時の曲率 $\phi_{0}$ は 式(2)として表される。

$$
\begin{aligned}
\mathrm{EI} & =\mathrm{EI}_{\mathrm{w}}+\mathrm{EI}_{\mathrm{s}} \\
\phi_{0} & =\mathrm{M}_{0} / \mathrm{EI} \\
& =\mathrm{M}_{0} /\left(\mathrm{EI}_{\mathrm{w}}+\mathrm{EI}_{\mathrm{s}}\right)
\end{aligned}
$$

$\mathrm{t}$ 時の曲げ剛性は集成材クリープにより $\mathrm{EI}_{\mathrm{w}}$ と $\mathrm{EI}_{\mathrm{s}}$ が低下するこ とを想定して式 (3) で表す。 $\mathrm{t}$ 時の曲率 $\phi \mathrm{t}$ は式 (4) として表される。

$$
\begin{aligned}
\mathrm{EI}_{\mathrm{t}} & =\alpha_{\mathrm{w}} \cdot \mathrm{EI}_{\mathrm{w}}+\alpha_{\mathrm{s}} \cdot \mathrm{EI}_{\mathrm{s}} \\
\phi & =\mathrm{M}_{0} / \mathrm{EI}_{\mathrm{t}} \\
& =\mathrm{M}_{0} /\left(\alpha_{\mathrm{w}} \cdot \mathrm{EI}_{\mathrm{w}}+\alpha_{\mathrm{s}} \cdot \mathrm{EI}_{\mathrm{s}}\right)
\end{aligned}
$$

$\alpha_{\mathrm{w}}$ は集成材の $\mathrm{EI}_{\mathrm{w}}$ の低下率で，集成材のクリープ係数の逆数と なる。 $\alpha$ s は鉄筋の EIs の低下率である。鉄筋と，鉄筋の接着剤で

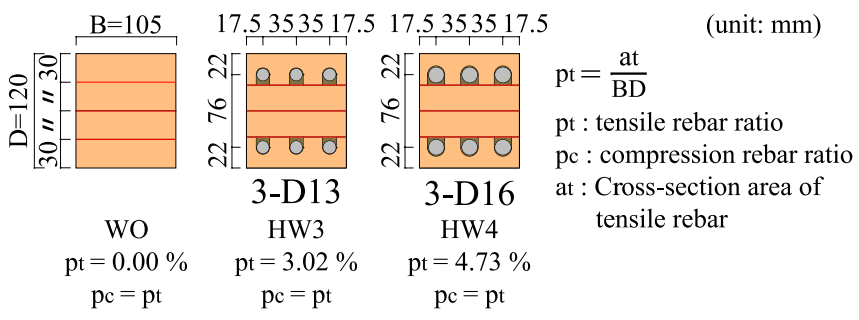

\begin{tabular}{|c|c|c|c|c|c|c|}
\hline \multirow{2}{*}{\multicolumn{3}{|c|}{$\begin{array}{c}\text { Glulam timber } \\
\text { Japanese ceder E65-255 }\end{array}$}} & \multicolumn{4}{|c|}{ Rebar(SD295) } \\
\hline & & & Dia. & $\mathrm{E}_{\mathrm{S}}$ & $\sigma_{\mathrm{y}}$ & $\sigma_{\mathrm{B}}$ \\
\hline $\mathrm{E}_{\mathrm{W}}$ & $\mathrm{G}_{\mathrm{W}}$ & $\mathrm{F}_{\mathrm{WB}}$ & D13 & $1.92 \times 10^{5}$ & 371 & 547 \\
\hline 8330 & 549 & 53.2 & D16 & $1.92 \times 10^{5}$ & 355 & 499 \\
\hline $\begin{array}{l}\mathrm{Ew}, \mathrm{Es} \\
\mathrm{Gw}: \mathrm{Sh} \\
\mathrm{F}_{\mathrm{WB}}: \mathrm{B}\end{array}$ & $\begin{array}{l}\text { ng } m \\
\text { ing } s\end{array}$ & & $\begin{array}{l}\text { Dai: } \\
\sigma_{y}: Y \\
\sigma_{B}:\end{array}$ & $\begin{array}{l}\text { meter } \\
\text { ld strength } \\
\text { king streng }\end{array}$ & & 1) \\
\hline
\end{tabular}

Fig. 3 Cross-sections of specimens

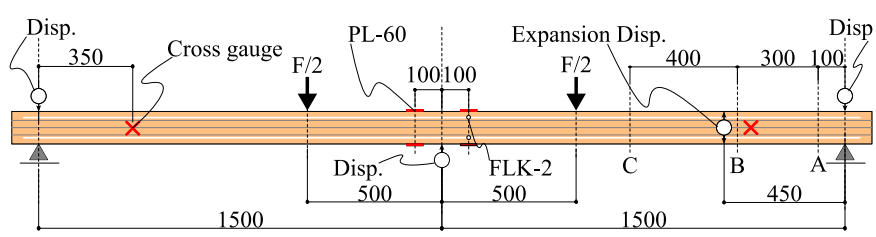

PL-60:Strain gauge on timber FLK-2:Strain gauge on rebar Disp. :Displacement Fig. 4 Arrangement of strain gauges and displacement transducers

Table 1 Mechanical property of materials by testing

はクリープは無視できるが，集成材のウェッブのせん断弾性係数が 低下すると，EIs の寄与効果が低下することが考えられる。これを 考慮するためにEIs 体となって平面保持の仮定に基づく曲げのひずみ分布に適合する場 合， $\alpha \mathrm{s}$ は 1.0 となり，適合しなくなると 1.0 より小さくなる。適 合しなくなることを，本論では「平面保持の仮定の崩れ」と呼ぶこ とにする。曲率のクリープ係数 $C_{\phi}$ は式 (5) で表される。式 (2) と 式（4）を代入して整理すると，式 (5) として表される。

$$
\begin{aligned}
\mathrm{C}_{\phi} & =\phi_{\mathrm{t}} / \phi_{0} \\
& =\left(\mathrm{EI}_{\mathrm{w}}+\mathrm{EI}_{\mathrm{s}}\right) /\left(\alpha_{\mathrm{w}} \cdot \mathrm{EI}_{\mathrm{w}}+\alpha_{\mathrm{s}} \cdot \mathrm{EI}_{\mathrm{s}}\right) \\
& =\left(1.0+\mathrm{EI}_{\mathrm{s}} / \mathrm{EI}_{\mathrm{w}}\right) /\left(\alpha_{\mathrm{w}}+\alpha_{\mathrm{s}} \cdot \mathrm{EI}_{\mathrm{s}} / \mathrm{EI}_{\mathrm{W}}\right)
\end{aligned}
$$

一方，鉄筋集成材は曲げ剛性を増加させるため，設計ではせん断 力が増加して曲げ変形成分に対してせん断変形が占める割合が大き くなる注 2)。せん断クリープも増加する。従って曲げ変形成分 $\delta_{\mathrm{b}}$ と せん断変形成分 $\delta_{\mathrm{s}}$ に分けて, たわみ $\delta \mathrm{t}$ を評価する必要がある。せ 几断変形成分 $\delta_{\mathrm{s}}$ の相対クリープ係数を $\mathrm{C}_{\gamma}$ とする。たわみは概念的 に式 (7) で表される。

$$
\delta_{\mathrm{t}}=\mathrm{C}_{\phi} \cdot \delta_{\mathrm{b}}+\mathrm{C}_{\gamma} \cdot \delta_{\mathrm{s}}
$$

\section{4. 長期載荷試験：試験 I}

\section{1 実験方法}

\subsection{1 試験体}

Fig.3 に梁断面を示寸。ラミナの厚さは $30 \mathrm{~mm}$ で，最外縁に鉄筋 を納めている鉄筋ラミナを接着している。Fig.4 に側面を示す。試 験体は各 1 体の計 3 体である。WO は集成材の梁で，HW3 と HW4 
は鉄筋集成材の梁である。長期載荷試験に先立ち同時に製作した 別の試験体 (WO, HW3, HW4) の短期載荷試験 ${ }^{3}$ を行い, 剛性と曲 げ耐力を把握している。集成材は 4 層ラミナを同一等級構成で接着 したものであり，強度等級 E65-F255，樹種はスギで縦継ぎはなし ，積層用接着剂は水性高分子イソシアネート系樹脂である。前頁の Table 1 に梁の短期載荷試験による集成材の機械的特性を示す。鉄 筋は材料試験結果である。鉄筋の溝寸法とエポキシ接着剂も文献 3)と同じで，そちらを参照されたい。

\section{1.2 載荷と測定}

Fig. 5 に加力状況を示す。三等区間 4 点曲げ載荷とした。 $\mathrm{H}$ 形鋼 梁への鉛直荷重はアーム式で加力した。長期載荷の荷重は，載荷を 開始した時点で，梁のスパン中央の純曲げ区間の集成材の曲げ応力 が等しくなるように設定した。室の温度と湿度は無調整とした。

Fig.4 に示すように中央たわみ, 支持点のめり込み変形, スパン 中央の，曲げ縁の集成材のひずみ（各 2 箇所, 検長 : $60 \mathrm{~mm}$ ) と鉄筋 のひずみ，せん断スパンの集成材のせん断ひずみ（クロスゲージ, 検長 : $60 \mathrm{~mm}$ ), 梁せいの伸縮変形 (A と B の間の位置), 上端と下 端の鉄筋の軸ひずみ (検長 : $2 \mathrm{~mm}$, 一箇所表裏), WO の含水率 (A,B,C 位置)，試験体の近傍の空気の湿度と室温，載荷用の鉄骨梁 の片側の支点の鉛直反力 $(F / 2)$ を測定した。鉛直荷重 $(F / 2)$ はロー ドセルにより管理した。ひずみは長期期間用ひずみゲージによって 測定した。考察では，曲率は曲げ縁のひずみゲージのひずみから算 出される值 (2 箇所の平均值) とし，せん断ひずみは対角線のひず みから算出される值とする。含水率は高周波含水率計で計測した。

\subsection{3 長期載荷時の応力と荷重および載荷履歴}

集成材の曲げ強度を $38.5 \mathrm{~N} / \mathrm{mm}^{2}$ とし, 集成材の曲げ縁の応力度を, その $1.1 / 3$ の值にする長期許容曲げモーメントを算出し， スパン中 央の曲げモーメントがその值となるように荷重を作用させた注3)。許 容曲げモーメントは平面保持の仮定に基づいて計算ている。この場 合の鉄筋の応力度は長期許容応力度に近い值になり，作用させた荷 重によるスパン中央のモーメントは鉄筋で決まる長期許容曲げモー メントともほぼ同值となった注?

Table 2 にせん断スパンの最大せん断応力度の計算值を示す。平 面保持の仮定に基づいて鉄筋を考慮して算出される形状係数 $\kappa_{\mathrm{m}}$ を 用いている。スギ集成材の長期許容応力度は $0.99 \mathrm{~N} / \mathrm{mm}^{2}$ であり, こ の值に対してWOは43\%で，HW3 は 120\% で，HW4 は 163\% であ る。HW4 は短期許容応力度 $\left(1.8 \mathrm{~N} / \mathrm{mm}^{2}\right)$ に近い応力度を生じさせて いる状態で長期載荷試験を実施していることになる。

Table 3 に鉛直荷重と載荷日を示す。HW3 は加力装置に問題が生 じて約 4 日半, 開始が遅れた。ロードセルの荷重は, 最初の 1 ケ月 間は毎日, 調整を行い, それ以降は 1 週間ごとに確認して調整した。 測定期間は現時点 (2020 年 12 月 9 日 ) で約 4 年間である。

\section{2 長期載荷の荷重導入時のモーメントー曲率関係}

Fig.6 に長期載荷導入時のスパン中央のモーメントー曲率関係を 示す。曲げモーメントは鉛直荷重による值とした。各試験体とも, 複数回, 載荷と除荷の繰返し加力を行ったため, ループを描いてい る。黒い一点鎖線は，短期載荷試験による実験值である。ピンクの 実線は，Table 1 の試験值を用いて計算した弾性の曲げ岡性による。 HW4 は本実験の剛性が，短期載荷の実験值と計算值とほぼ一致し ている。HW3 は本実験值が多少，大きくなっている。WO は実験

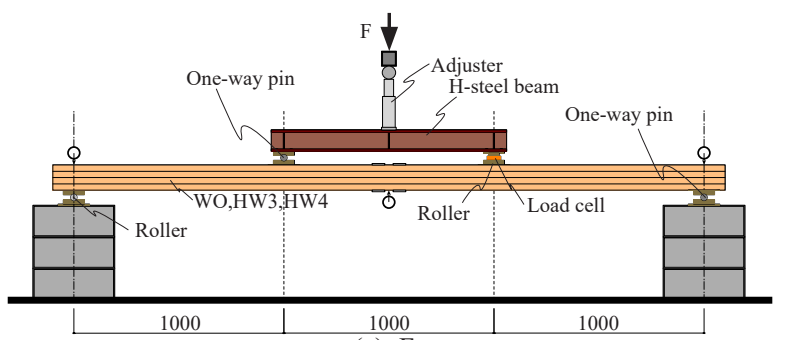

(a): Front

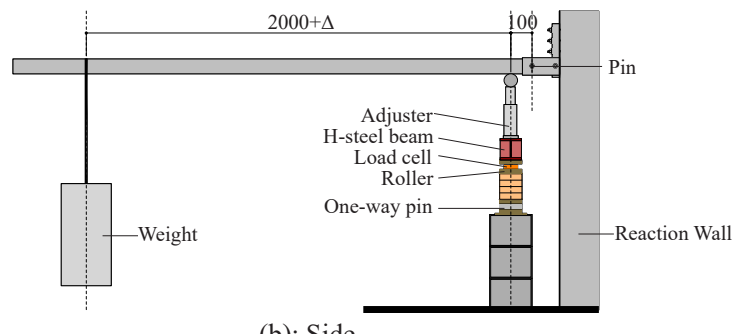

(b): Side

Fig. 5 Setup for long-term four-point deflection test

Table 2 Maximum shear stress of web's wood of beam

\begin{tabular}{|c|c|c|c|c|}
\hline \multirow{2}{*}{ Specimen } & \multicolumn{3}{|c|}{ Maximum shear stress: $\tau_{\mathrm{m}}$} & \multirow{2}{*}{$\begin{array}{c}\text { Note } \\
\text { Q: Shear force at }\end{array}$} \\
\hline & $\mathrm{Q}(\mathrm{kN})$ & $\kappa_{\mathrm{m}}$ & $\tau_{\mathrm{m}}\left(\mathrm{N} / \mathrm{mm}^{2}\right)$ & \\
\hline WO & 3.62 & 1.500 & 0.43 & shear span \\
\hline HW3 & 9.81 & 1.525 & 1.19 & $\kappa_{\mathrm{m}}:$ Shape factor of \\
\hline HW4 & 13.31 & 1.529 & 1.62 & shear stress \\
\hline
\end{tabular}

Table 3 Start date of loading, Force F, and deflection

\begin{tabular}{ccccc}
\hline \multirow{2}{*}{ Date } & \multicolumn{4}{c}{ Vertical load F and Deflection $\delta$} \\
& Items & WO & HW3 & HW4 \\
\hline \multirow{2}{*}{$2016 / 12 / 17$} & Load(kN) & 7.12 & - & 26.62 \\
& Deflection(mm) & 32.9 & - & 29.8 \\
\hline \multirow{2}{*}{$2016 / 12 / 22$} & Load(kN) & $\downarrow$ & 19.62 & $\downarrow$ \\
& Deflection(mm) & $\downarrow$ & 27.5 & $\downarrow$ \\
\hline
\end{tabular}

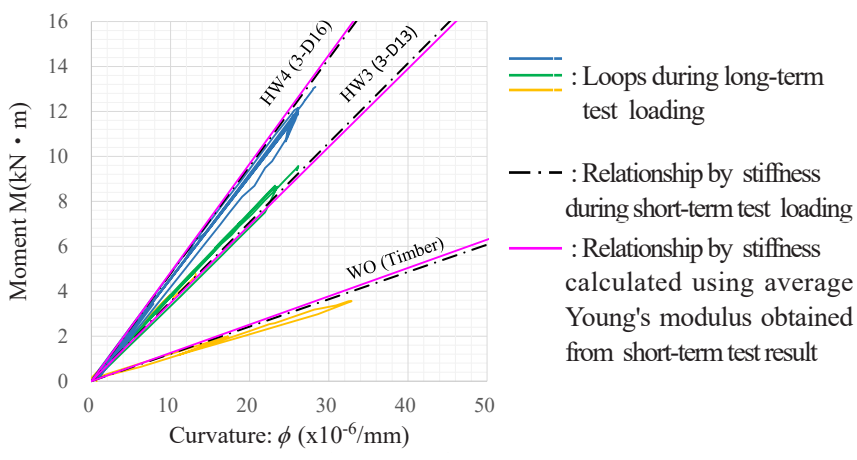

Fig. 6 Bending moment - curvature relationship at mid-span during loading up to target load for long-term deflection test I
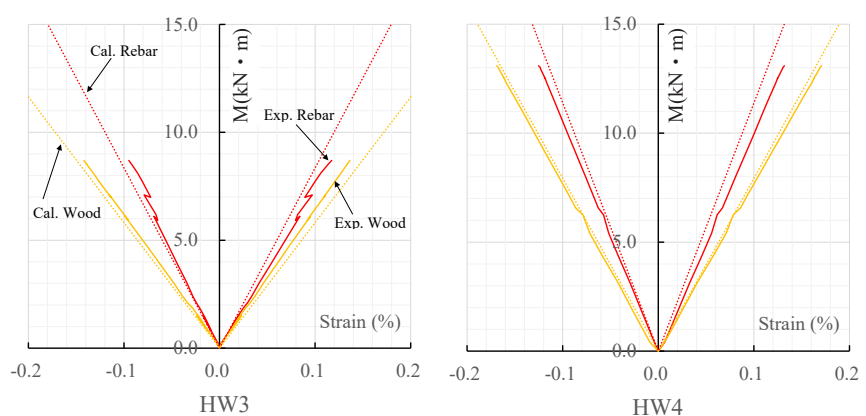

Fig. 7 Bending moment-rebar strain and wood strain relationships at midspan during loading up in Test I 
值が，多少小さくなっている。集成材のヤング係数のバラツキが影 響していると考えられる。

Fig.7 に荷重導入時の HW3 と HW4 の鉄筋の軸ひずみと集成材の 曲げ縁の軸ひずみと，モーメントの関係を実線で示す。平面保持の 仮定に基づく各ひずみの計算值も点線で示している。計算值は実験 值を概水推定しており，短期荷重時は，鉄筋集成材の断面では平面 保持の仮定に従って鉄筋と木部が曲げ抵抗していると判断できる。

WO に対する HW3 と HW4 の曲げ剛性の増加率は Fig.6 の実験值 に基づくと，それぞれ 3.33 と 4.19 であった。鉄筋と，鉄筋の接着 剂のクリープを無視すると集成材の曲率のクリープと，そのバラッ キは HW3 で 30\% 以下に HW4 で $23 \%$ 以下に抑制されることになる ${ }^{2} 4$ 。

\section{3 長期載荷時の測定結果}

Fig. 8 から Fig.14 に荷重, 温度, 湿度, 含水率, スパン中央のたわみ, 曲率，せん断ひずみ，鉄筋の軸ひずみ，梁せいの伸縮，これらの 初期值からの増加量およびクリープ係数の経時変化を示す。Table 5 に初期值を示す。Fig.8 にスパン中央のたわみとロードセルの荷重 を示す。たわみは左右の支点のめり込みを差し引いている。荷重は F の $1 / 2$ である。相対クリープ係数の初期值は載荷開始から 10 分 後の值とした。たわみとひずみの増加傾向から 5 つの期間に分けた。 Table 4 に各期と日付を示す。 2 年目以降は IV 期 (7-9 月期) と V 期 が繰り返されている。各図に各期の境界の日を縦線で示している。

I期ではたわみと曲率およびせん断ひずみとも増大しており，そ

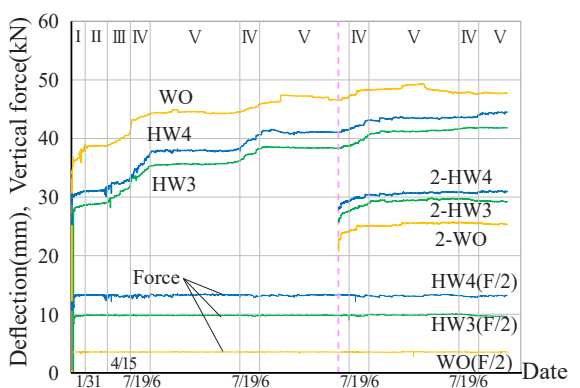

Fig. 8 Deflection at mid-span, vertical force - elapsed date

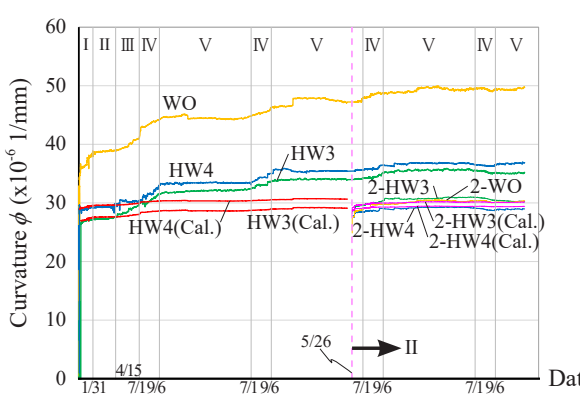

(a) Curvature

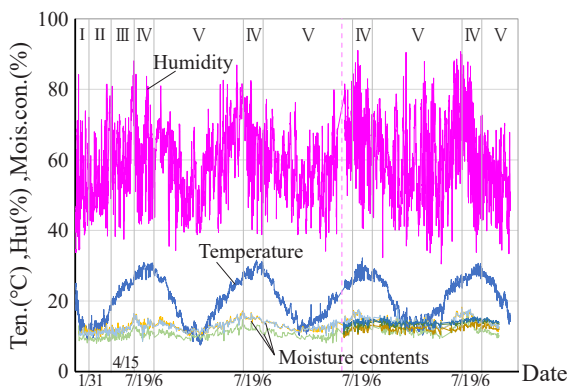

Fig. 9 Temperature, humidity around specimens and moisture contents of WO specimen

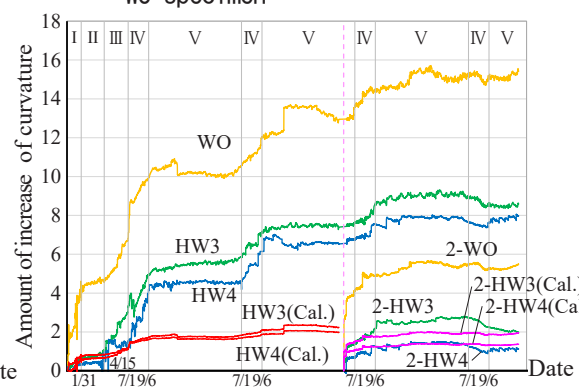

(b) Amount of increase from start

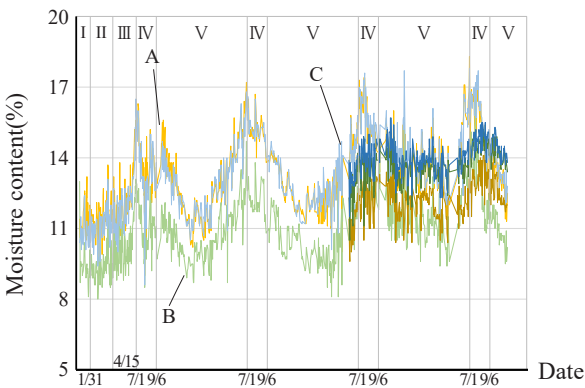

Fig. 10 Moisture contents of WO specimen

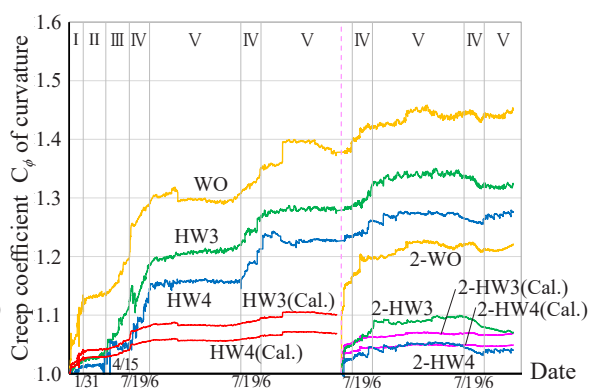

(c) Relative creep $\mathrm{C}_{\phi}$

Fig. 11 Curvature-elapsed date relationship of experiment and calculation by Eq. (6)

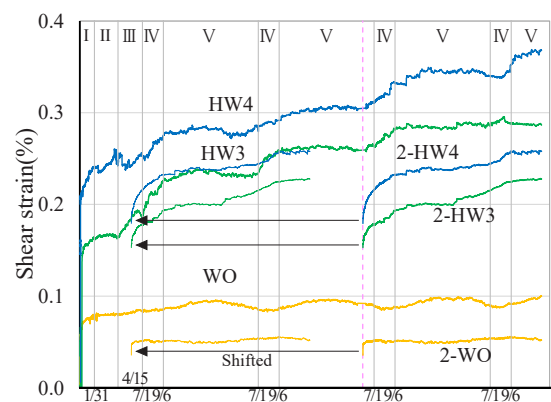

(a) Shear strain

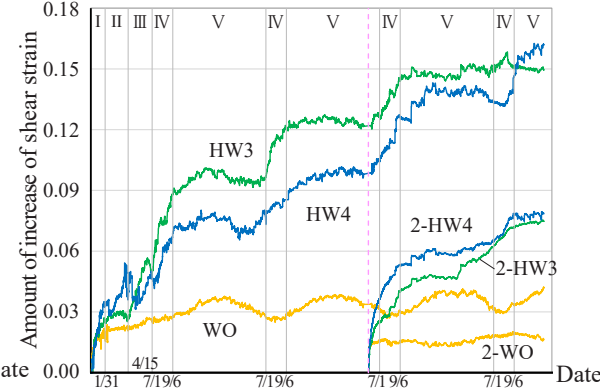

(b) Amount of increase from start

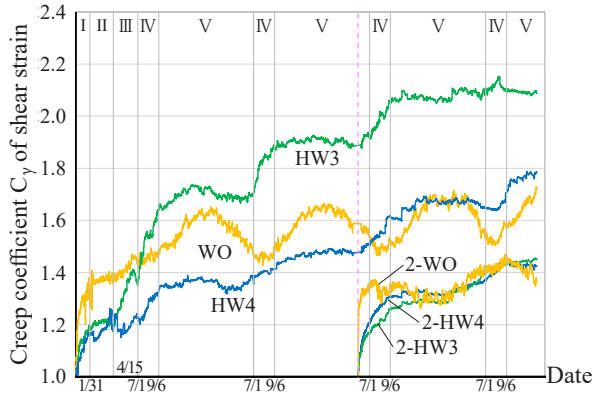

(c) Relative creep $\mathrm{C}_{\gamma}$

Fig. 12 Shear strain-elapsed date relationship of experiment

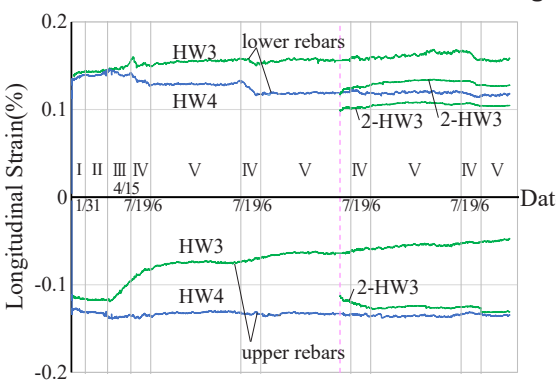

Fig.13 Axial strain-elapsed date relationship of rebars

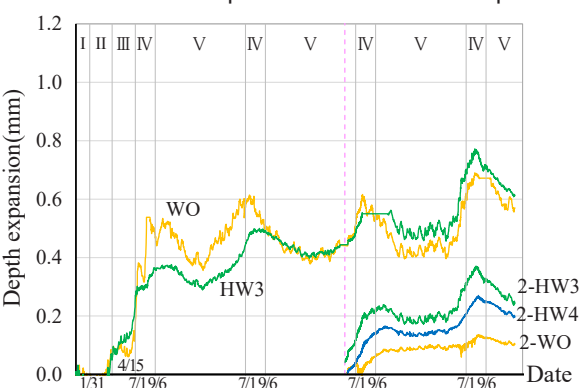

Fig.14 Expansion -elapsed date relationship of web in depth

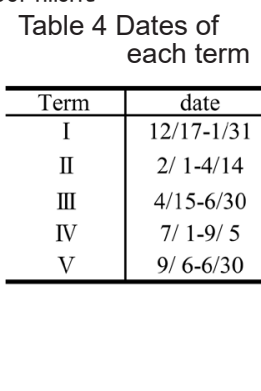

Table 5 Initial values for relative creep

\begin{tabular}{llll}
\hline Test I & WO & HW3 & HW4 \\
\hline
\end{tabular}

$\begin{array}{llll}\delta_{0} & 34.2 & 30.8 & 29.8\end{array}$

$\begin{array}{llll}\phi_{0} & 34.3 & 26.6 & 28.9\end{array}$

\begin{tabular}{llll}
$\gamma_{0}$ & 0.058 & 0.137 & 0.206 \\
\hline
\end{tabular}

\begin{tabular}{llll}
\hline Test II $2-W O$ & $2-H W 3$ & $2-H W 4$ \\
\hline
\end{tabular}

\begin{tabular}{cccc}
\hline$\delta_{0}$ & 20.7 & 25.9 & 27.9 \\
$\phi_{0}$ & 24.9 & 28.2 & 28.0
\end{tabular}

\begin{tabular}{llll}
$\gamma_{0}$ & 0.036 & 0.153 & 0.179 \\
\hline
\end{tabular}

Deflection (mm)

$\phi_{0}$ : Curvature $\left(10^{-6} / \mathrm{mm}\right)$

$\gamma_{0}$ : Shear strain $(\%)$ 
の増大は, 含水率と室温が大きく変動していない期間なので, 一次 クリープと見なせる。Fig.11 に式 (6) による曲率と曲率の増加量お よびクリープ係数 $\mathrm{C}{ }_{\phi}$ の計算值の変化を赤線で示す。集成材の $\mathrm{EI}_{\mathrm{w}}$ の低下率 $\alpha_{\mathrm{w}}$ はWO の曲率のクリープ係数の実験值の逆数とし, 鉄 筋の曲げ剛性 $\mathrm{EI}_{\mathrm{s}}$ は低下しないものとし $\alpha \mathrm{s}$ を 1.0 とした。

HW3 と HW4 の I 期では計算値は実験值の増加をほぼ推定してい る。HW3 と HW4 の曲率の増加はWO の増加の $18 \%$ 以下に抑制さ れた。これは, 前述の短期載荷試験の曲げ剛性から予測した比率 4) にほぼ対応している。しかし, これ以降, III 期または IV 期では 実験の曲率は急増し, その増加速度は計算值の速度と乘離している。

同期では集成材梁 WO は曲率が急増しており湿度と含水率の増 減の状況から MS クリープの影響を受けていると考えられる。長期 載荷開始の時点では, 各試験体の集成材の曲げ応力度は計算上, 同 じ值としているので, 鉄筋集成材内の集成材でも同程度の MS クリ 一プの影響を受けていることになる。式(6)の計算值では, 集成材 で生じる MS クリープの影響をWO のクリープ係数として, ある程 度, 考慮している。計算值は I 期と II 期の曲率のクリープの変化を ほぼ評価できているので, 実験值が計算值に対して乘離している III 期と IV 期の鉄筋集成材梁では, 式 (6) の誘導で仮定している事項が 成立しない状況になっていると考えられる。

この期間では曲げ圧縮縁と曲げ引張縁の木部の軸ひずみが各方向 に増大して曲率が増大した。一方, Fig.13 を観ると, HW3 は III 期 から上端の圧縮鉄筋のひずみが急激に減少し，下端の引張鉄筋のひ ずみは僅かに増加している。 HW4 は下端の引張鉄筋のひずみが III 期から僅かに減少が始まっているが，HW3 の圧縮鉄筋のひずみの 減少速度ほどではない。IV 期になるとその引張鉄筋のひずみの減 少速度は，III 期に比べて速くなっている。これは, Fig.11(b)の曲 率の増加速度と対応している。梁の曲げモーメントは一定なので, 鉄筋が負担する曲げモーメント成分が低下し，集成材の負担する曲 げモーメント成分が増加して曲率速度が増加したと解釈できる。

4.2 節で示したように荷重を導入する際の曲げ剛性は平面保持の 仮定により評価できた。クリープにより集成材の曲げヤング係数は 低下寸るが，鉄筋のヤング係数は低下しない。梁断面に平面保持の 仮定が成立するのであれば，上端筋と下端筋ともひずみは増大する はずである。しかし，前述の集成材と鉄筋のひずみの増減は全く逆 の現象になっている。III 期と IV 期では平面保持の仮定に従わない 鉄筋の抵抗の変化が生じていることになる。すなわち平面保持の仮 定の崩れが生じていることになる。

\section{4 平面保持の仮定の崩れの要因}

III 期と IV 期では Fig.9 と Fig.10 で見られるように湿度と含水率 とが高い水準である。Fig.14の梁せいの膨張からも水分は浸透して いると判断できる。HW4 は変位計に不具合があり, 示していない。 含水率の増減により, 一般の小・中断面の集成材梁では MS クリー プが生じる。しかし, 前述した式 (6)による曲率の計算では, 集成 材梁の曲率のクリープ成分にはWOの成分を用いており，その計 算值に既に集成材の MS クリープの成分はほぼ考慮されていると考 えるべきである。2 章で述べたように R. Kliger ら ${ }^{11}$ は, 補強材を 引張側と圧縮側に接着すると, MS クリープを抑制できることを指 摘している。HW3 と HW4 の III 期と IV 期の曲率の増加量は平面保 持の仮定が成立する状況であれば, WO で生じる曲率の増加量の、 HW3 で $30 \%$ 以下に HW4 で $23 \%$ 以下に抑制されるはずであるが， ほぼWOの増加量と同じになっている。本試験体の HW3 と HW4 は, 相当量の鉄筋を配筋しており，MS クリープが，その III 期と IV 期 の曲率の急増の主要因と考えられない。このほかの要因としてはク リープによるウェッブのせん断剛性の低下により, 平面保持の仮定 が成立しにくい状況に陥ることが考えられる。これについては数值 解析モデルで本試験体のせん断クリープが曲率に及ぼす影響 ${ }^{20)}$ 報告しているが，それによる曲率の増加は $0.01 \times 10^{-6} 1 / \mathrm{mm}$ 程度で, ウェッブのせん断ひずみの増加量で説明できる状況でなかった。

これらのことから MS クリープとせん断クリープが主要因でない と推論できる。しかし曲率の急増の III 期と IV 期では集成材の含水 率と室温が高い水準で, これらが影響を与えていると考えられる。

\section{5．吸湿と脱湿を防いだ長期載荷試験：試験 II}

集成材の含水率の変動の影響を明らかにする目的で集成材の表面 を接着剂によりコーティングした梁の長期載荷試験を行った。

\section{1 試験体と実験方法}

試験体の断面と形状および試験体数は試験 I と同じとした。製造 も同じとした。違いは集成材の全面にエポキシ接着剤を塗布したこ

Table 6 Bending stress and shaer stress of Test I and Test II

\begin{tabular}{|c|c|c|c|c|c|c|c|c|c|}
\hline \multirow{2}{*}{ Specimen } & \multirow{2}{*}{$\begin{array}{c}\mathrm{F} / 2 \\
(\mathrm{kN})\end{array}$} & \multirow{2}{*}{$\begin{array}{l}\mathrm{Ws} / 2 \\
(\mathrm{kN})\end{array}$} & \multirow{2}{*}{$\begin{array}{c}\omega \\
(\mathrm{kN} / \mathrm{m}) \\
\end{array}$} & \multicolumn{2}{|c|}{ Test I } & \multicolumn{2}{|c|}{ Test II } & \multirow{2}{*}{$\sigma_{f} / \sigma_{\text {fo }}$} & \multirow{2}{*}{$\tau_{\mathrm{m}} / I_{\mathrm{mo}}$} \\
\hline & & & & $\sigma_{f_{0}}$ & $\tau_{\text {mo }}$ & $\sigma_{f}$ & $\tau_{\mathrm{m}}$ & & \\
\hline $2-W O$ & 3.62 & & 0.047 & 14.64 & 0.44 & 13.01 & 0.39 & 0.89 & 0.88 \\
\hline 2-HW3 & 9.81 & 0.29 & 0.079 & 14.16 & 1.20 & 13.47 & 1.14 & 0.95 & 0.95 \\
\hline 2-HW4 & 13.31 & & 0.105 & 14.09 & 1.64 & 13.52 & 1.56 & 0.96 & 0.95 \\
\hline
\end{tabular}

$\tau_{\mathrm{mo}}, \tau_{\mathrm{m}}:$ Shear force and maximum shear stress at shear span

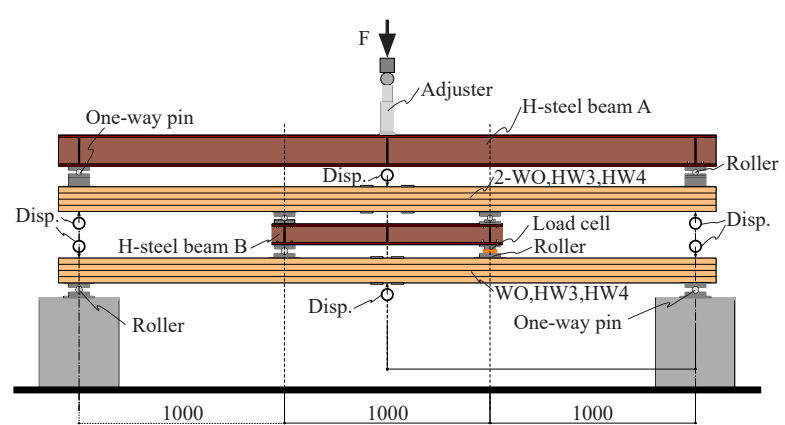

(a): Front

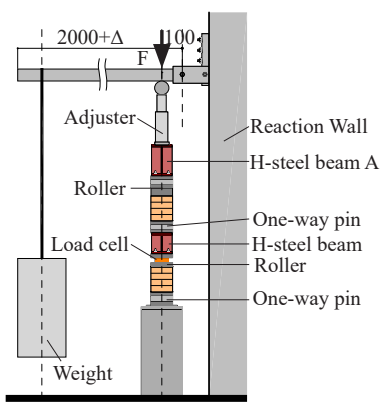

(b): Side
Fig. 15 Setup for long-term four-point loading from Test II

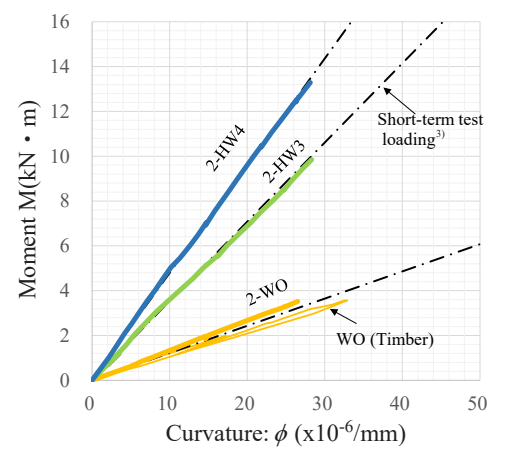

Fig. 16 Bending moment - curvature relationship at mid-span during loading up to target load for Test II 


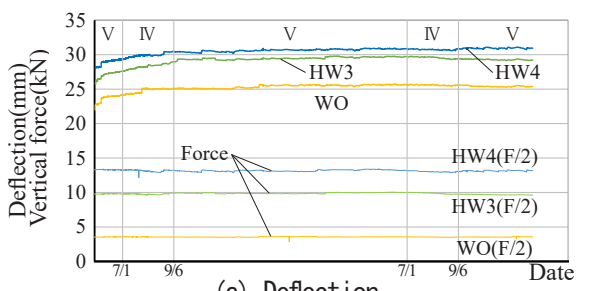

(a) Deflection
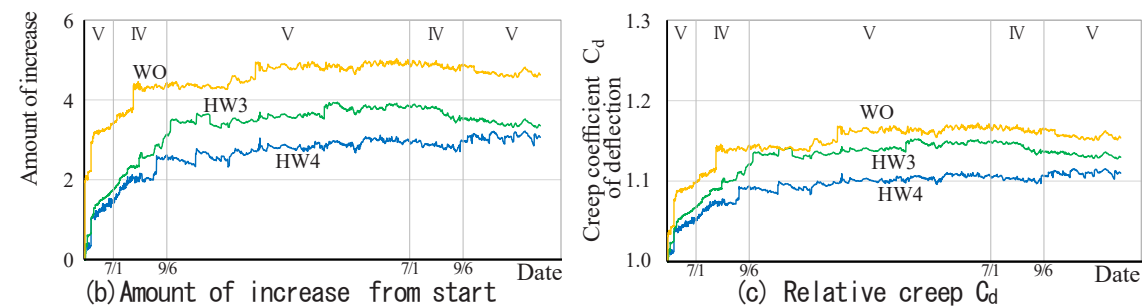

Fig.17 Deflection-elapsed date relationship of experiment and calculation by Eq. (6) of Test II

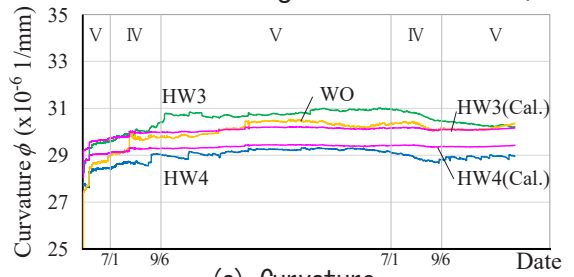

(a) Curvature

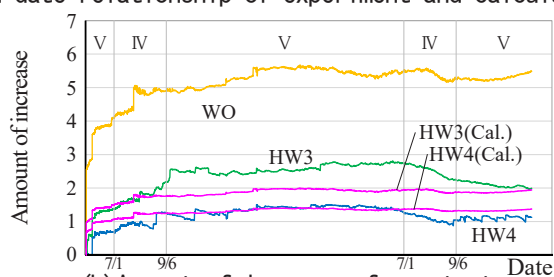

(b) Amount of increase from start

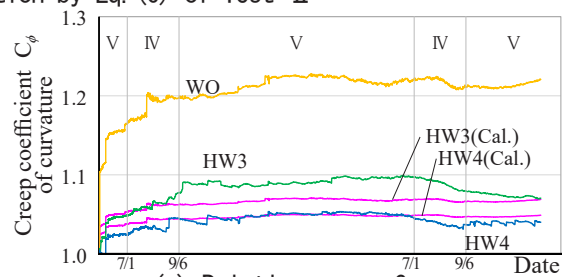

(c) Relative creep $\mathrm{C}_{\phi}$
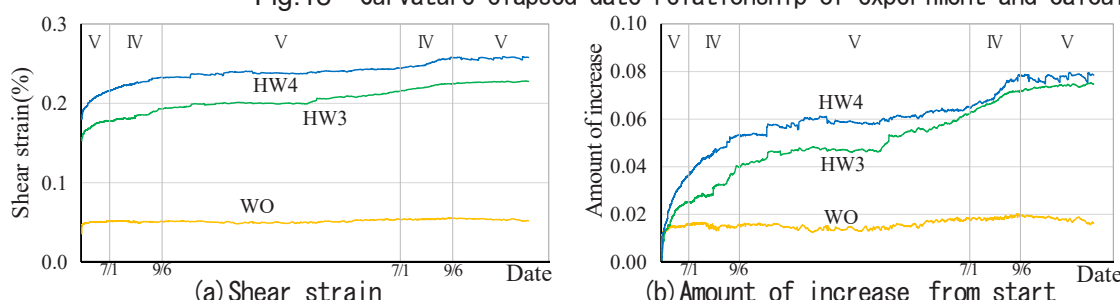

(b) Amount of increase from start Dare

Fig.19 Shear strain-elapsed date relationship of Test II

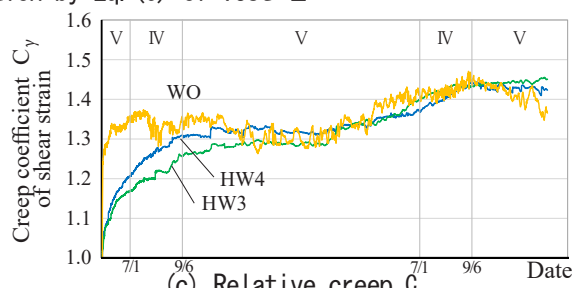

(c) Relative creep $\mathrm{C}_{\gamma}^{71}$

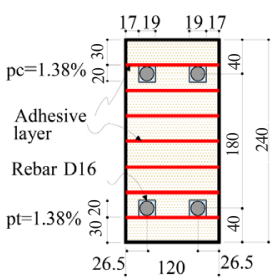

(a)

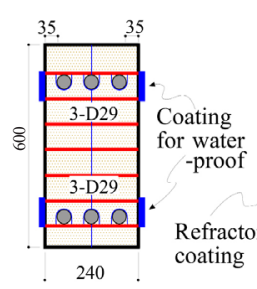

(b)

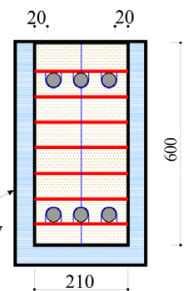

(c)

(a) Hira's section of test of humidifying to creep

(b) Fireproof section by using burning marginal layer

(c) Fireproof section by using refractory coatings

Fig.20 Section of beam of Hira et al. ${ }^{19)}$ and protection methods of moisture form precolating into rebar-embeded lamina 荷重 $(\mathrm{F} / 2)$ より小さくなっている。更に, 試験 I と試験 II のたわみ の形状は上下対称になり，両者のたわみの向きに対して，梁の自重 の作用方向が逆になる。試験 I では, 梁の自重はたわみを増加させ て, 試験 II では, 減少させる。Table 6 にロードセルの荷重 $(\mathrm{F} / 2)$, 鉄骨梁 B の重量 (Ws) の $1 / 2$, 梁の自重の線荷重 $(\omega)$, これらの 重量を考量して計算されるスパン中央の集成材の曲げ応力度（ $\sigma_{\mathrm{f} 0}$ ,$\left.\sigma_{\mathrm{f}}\right)$ ，およびせん断スパンの最大せん断応力 $\left(\tau_{\mathrm{m} 0}, \tau_{\mathrm{m}}\right)$ を示す。 2-WO は作用荷重 F が他の試験体に比べ小さいので, 鉄骨梁と梁の 自重の影響が大きくなる。集成材の曲げ応力度は, 試験 I の WO に 比べ 0.89 に減少する。せん断応力度も同様に減少する。

2019 年 5 月 11 日に試験 I の長期載荷を一時的に除荷し, 同年 5 月 27 日から試験 I と II の長期載荷を再開した。

測定については集成材の製造時に 2-HW4 では鉄筋のひずみゲー ジがほとんど損傷して測定が不可能になった。せん断ひずみは左右 のせん断スパンに増やした。これら以外は試験 I と同じである。

\section{2 長期荷重導入時のモーメントー曲率関係}

Fig. 16 に長期載荷導入時のスパン中央の曲げモーメントー曲率関 係を示す。表示は Fig.6 と同じである。一点鎖線は，短期載荷試験 の関係である。2-HW3 と2-HW4 は，それぞれの一点鎖線に，ほぼ 一致しており，Fig.6の HW3 と HW4 と，それぞれ同程度の曲げ剛

性である。2-WO は一点鎖線より大きく, WO の曲げ剛性の約 1.35 倍となった。木材のバラツキと考えられる。これは, 後述するたわ みの初期值に影響を与えることになる。

\section{3 実験結果}

Fig.8 と Fig.11 から Fig14 に試験 II の結果を挿入している。Table 5 に試験 II の各成分の初期值を，試験 I と同様に示している。

長期載荷開始時の初期值が試験 II 試験体の方が試験 I の初期值よ り小さくなっている。原因は，前節で述べた試験体の段積みによる 荷重の違いである。特に2-WO の違いが大きい。

Fig.8,11,14 において試験 I の試験体は IV 期 (7-9 月期 ) で曲率, たわみ, 梁せいの膨張が増加しているが，これに対して試験 II は, それらの増加速度は, 極めて緩やかである。

Fig.17 から Fig.19 に試験 II のの経時変化を示す。Fig.18 に鉄筋 集成材梁 (2-HW3, 2-HW4) の計算值もピンクの線で示す。2-WO の 曲率の相対クリープ係数の実験值の逆数を $\alpha_{\mathrm{w}}$ として式 (6)により計 算している。試験 I で見られた III 期と IV 期の急増が生じていな いため, 計算值は実験值を概ね推定している。試験 II では平面保 持の仮定の崩れはほとんど生じていないと考えられる。Fig.13には 


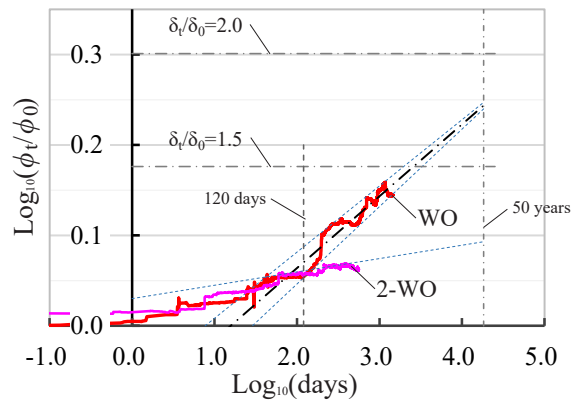

(a) WO

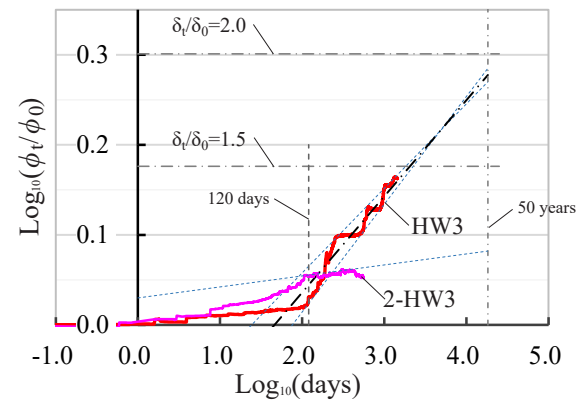

(b) HW3

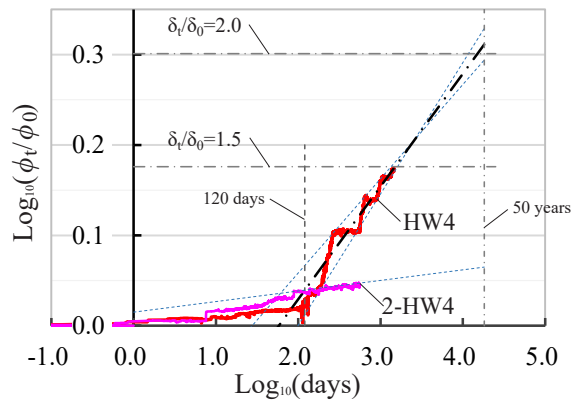

(c) HW4

Fig. 21 Relationship of $\log 10\left(\delta_{t} / \delta_{o}\right)-\log 10($ days $)$ of Test I : Deflection

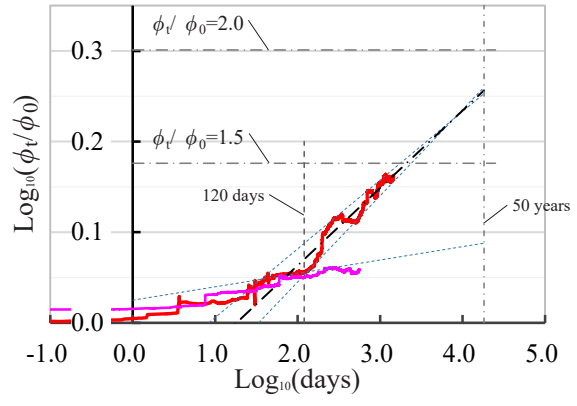

(a) WO

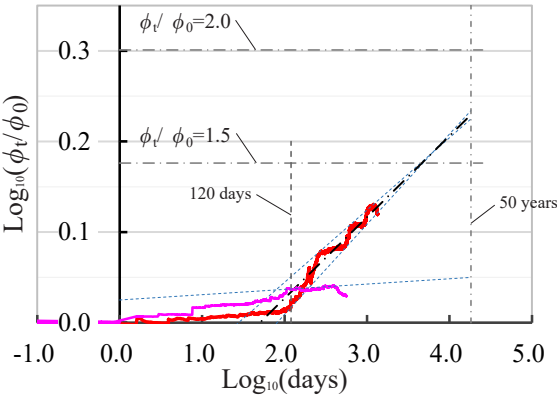

(b) HW3

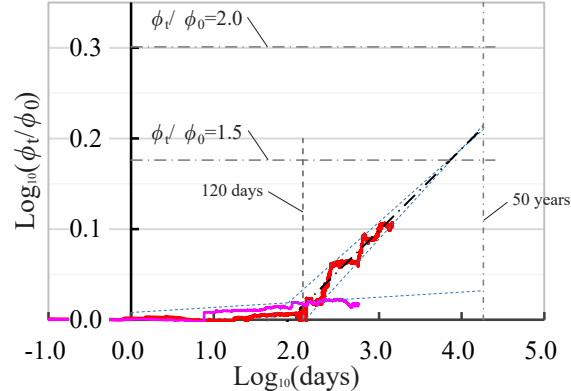

(c) HW4

Fig. 22 Relationship of $\log _{10}\left(\phi_{t} / \phi_{0}\right)-\log _{10}($ days $)$ of Test I : Curvature

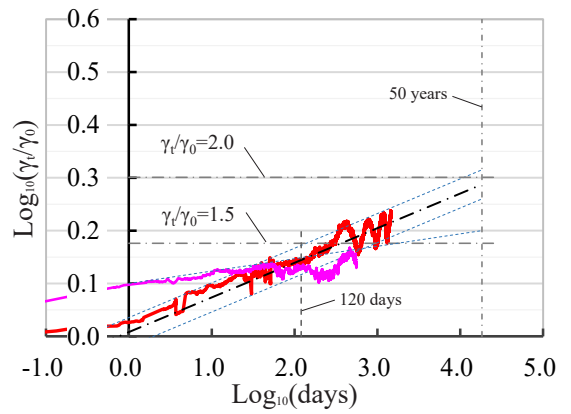

(a) WO

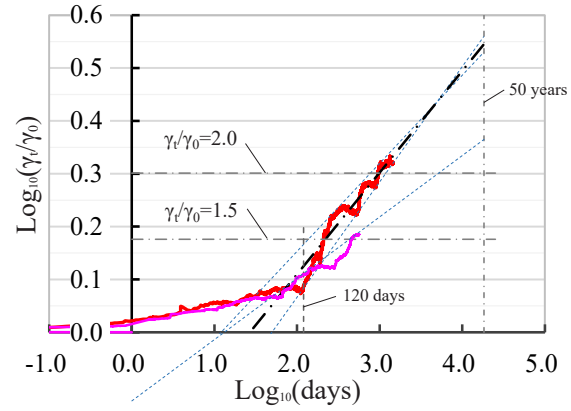

(b) HW3

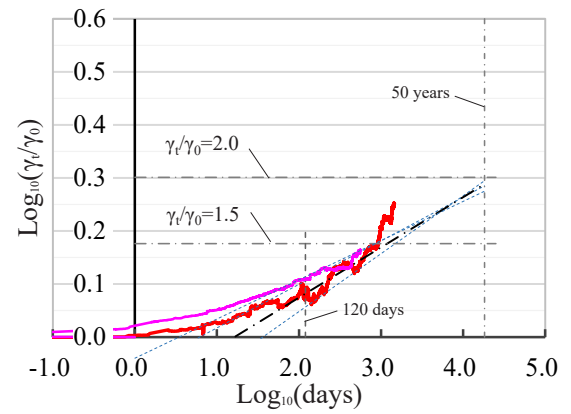

(c) HW4

Fig. 23 Relationship of $\log _{10}\left(\gamma_{t} / \gamma_{0}\right)-\log _{10}($ days $)$ of Test I : Shear strain

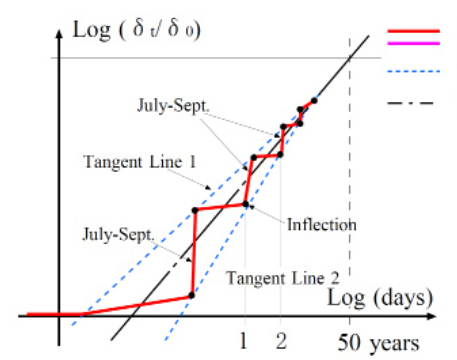

(a) Test I
Fig.24 Schematic relationship relative creep and time by logarithm and convergence of variation amount of creep

2-HW3 のみの鉄筋のひずみの挙動を挿入している。下端の引張鉄 筋は 2 箇所, 上端の圧縮鉄筋は 1 箇所である。下端筋のひずみは, ひずみの量に多少差があるが変化傾向は同じである。上端筋のひず みは正負の違いはあるが, その量の変化傾向は下端筋とほぼ同様で ある。試験 II では試験 I の HW3 の上端筋と HW4 の下端筋の III 期 と IV 期で生じたひずみの急激な減少が生じていない。このことか らも試験 II では平面保持の崩れは生じていないと考えられる。

Fig.12(a) において試験 II の試験体のデータを 2017 年に 2 年前倒 しして水平移動させた線を細線で示寸。色は同じとしている。その
試験 II のせん断ひずみは, 試験 I で現在の 12 月 9 日では, 試験 I の值に対して, WO は 57\% で2-HW3 は 87\%，2-HW4 は 85\%，とな つている。ひずみ量が減少しているのは, Table 6 で示したせん断 応力の減少と, 試験体をコーティングしたことが影響を与えている と考えられる。せん断ひずみは, 試験 II の鉄筋集成材試験体でも 試験 I に近い值となっている。しかし, 前述したように試験 II の曲 率の経時変化を平面保持の仮定に基づいて計算されるクリープ係数 でほぼ実験結果を推定できている。このことを考えると, 試験 I や 試験 II の鉄筋集成材梁の試験体に生じているせん断ひずみの量は 平面保持の仮定を崩すまではないと推論できる。これは既報の解析 結果 ${ }^{20)}$ と一致する。従って試験 I で生じた平面保持の仮定の崩れ により曲率が増大寸る現象の主原因は, ウェッブのせん断ひずみの 増大以外の, 集成材の吸湿・脱湿に関連する他の要因と推論できる。

\section{4 主原因の推論と対策}

鉄筋と鉄筋の接着剂のクリープは年間気温の変動の範囲では極め て小さい。試験 II の 2-HW3 と2-HW4 の曲率が安定していること で確認できる。試験 I の急増の原因は, 集成材の表面からの吸湿に より, その位置に近い鉄筋の回りの木部のせん断剛性の低下が有力 と考えられる。木表面からの水分の浸透深さは 1 ケ月間の梅雨時期 
では $16 \mathrm{~mm}$ 程度とされている ${ }^{21)}$ 。Fig.3 で確認できるように鉄筋の 回りの木部はその範囲に存在するので, その部分の含水率は集成材 内部の含水率に比心゙て極めて大きく, その水分による剛性の低下は 集成材内部に比べて大きいと考えられる。鉄筋まわりの木部のせん 断剛性が低下し，梁の曲げモーメントを負担する鉄筋の軸応力が低 下して集成材が負担する曲げモーメントが増大して，鉄筋集成材梁 の曲率の実験值が式 (6) による計算值を上回ったと考えられる。

清藤ら ${ }^{22)}$ は鉄筋まわりの木部のせん断剛性を HW3 では約 $20 \%$, HW4 では約 35\% に低下させると試験 I の曲率の増加を解析的に説 明できることを報告している。また比良ら ${ }^{19)}$ は強制加湿によりク リープの進行を促進させて集成材の曲げクリープを鉄筋により抑制 する実験を報告している。その梁断面を Fig.20(a) に示す。断面に おける鉄筋量は少ないが，3 万月間，強制加湿を行っても，平面保 持の仮定に基づいて鉄筋集成材梁の曲率の増加量を評価できること を報告している。上下の曲げ縁に接着されたラミナの接着層が鉄筋 ラミナへの水分の浸透を防止して鉄筋まわりの木部のせん断剛性の 低下を抑制したと考えられる。

長期使用下でも鉄筋による梁の曲げ岡性の増加効果を維持させる ためには, Fig.20(b) に示すように上下の最外層にラミナを接着して 鉄筋ラミナの上下面に対寸る水分の浸透を, ラミナの接着層で防ぎ, そのラミナの側面に一定の木材被覆を確保するまたはコーティング することが考えられる。鉄筋集成材は大断面を想定しており，燃え 代設計の仕様にする場合は側面の木材被覆も十分, 確保できる。

Fig.20(c) は耐火部材とする場合で，耐火被覆で覆われるので，浸 透を緩和また防止できる工夫は可能である。

\section{6. クリープ調整係数}

\section{1 季節要因による変動量を伴うクリープ係数の評価の研究}

温湿度が制御されていない環境では季節によりクリープの変動量 が大きくなる。その代表的なクリープとして MS クリープがある。 荒武ら ${ }^{17)}$ は，MS クリープの有無に関係なく，長期載荷試験を開始 してから，一定期間（6ヶ月間）を経過した以降の一定の期間のデ 一タに対して Power 則の式を用いて回帰直線式を求めて 50 年後の クリープ調整係数を推測することを推奨している。ラミナ構成が対 称な集成材では 1 年以上の測定期間，ラミナ構成が非対称な集成材 では MS クリープの変動が増大寸るので 2 年以上の測定期間を推奨 している。そこでは 4 年間, 計測が行われ，50 年後のクリープ調 整係数の安定性を確認している。

\section{2 季節要因による変動量の収束性に基づく相対クリープ係数}

Fig.21 から Fig.23 に試験 I のたわみとひずみの相対クリープ係数 と経過時間を常用対数に換算して表示した経時変化 (赤線)を示す。 スパン中央のたわみと曲率およびせん断スパンのせん断ひずみであ る。図中に 120 日経過時を鉛直の破線で示す。初年度の 3 月末日に 相当する。載荷開始からの変化傾向と, 破線以降の変化傾向は明ら かに異なっている。各相対クリープ係数が急増する時期がある。こ れが III 期と IV 期である。ほとんどの係数は，Fig.24(a) に示すよう に階段状に変化している。しかし, その変化は一定の傾きの直線 (一点鎖線）を軸に振動しながら，その振幅が減衰する変化とも見 なせる。正負の最大振幅に対して，それぞれの接線（青の破線）を 描くと, それらの間で，最大振幅が減衰する变化になっている。振
Table 7 Power law constants and relative creep in 50 years

\begin{tabular}{c|c|ccc|ccc|ccc}
\hline \multirow{2}{*}{ Test } & \multicolumn{3}{|c|}{ Deflection } & \multicolumn{3}{c|}{ Curvature } & \multicolumn{3}{c}{ Shear strain } \\
\cline { 3 - 11 } \multicolumn{2}{c|}{} & $\alpha$ & $\mathrm{N}$ & $\delta_{50} / \delta_{0}$ & $\alpha$ & $\mathrm{N}$ & $\phi_{50} / \phi_{0}$ & $\alpha$ & $\mathrm{N}$ & $\gamma_{50} / \gamma_{0}$ \\
\hline \multirow{2}{*}{$\mathrm{I}$} & WO & 0.80 & 0.08 & 1.75 & 0.78 & 0.09 & 1.81 & 0.88 & 0.08 & 1.94 \\
& $\mathrm{HW} 3$ & 0.66 & 0.11 & 1.89 & 0.70 & 0.09 & 1.70 & 0.53 & 0.19 & 3.51 \\
& $\mathrm{HW} 4$ & 0.60 & 0.12 & 2.05 & 0.67 & 0.09 & 1.63 & 0.77 & 0.09 & 1.94 \\
\hline \multirow{3}{*}{$\mathrm{II}$} & 2-WO & 1.07 & 0.01 & 1.24 & 1.06 & 0.01 & 1.22 & 1.26 & 0.02 & 1.58 \\
& 2-HW3 & 1.07 & 0.01 & 1.21 & 1.06 & 0.01 & 1.12 & 0.74 & 0.12 & 2.32 \\
& 2-HW4 & 1.04 & 0.01 & 1.16 & 1.02 & 0.01 & 1.08 & 0.91 & 0.07 & 1.88 \\
\hline
\end{tabular}

$\alpha=\mathrm{A} / \delta_{0}$ : relative creep one day after loading, $\mathrm{N}$ : Deceleration exponential $\delta_{50} / \delta_{0}$ : relative creep in 50 years, Curvature and shear strain are expressed as well as $\delta$. $\mathrm{C}_{\mathrm{pi}}=\alpha \cdot \mathrm{t}^{\mathrm{N}}$ where $\mathrm{C}_{\mathrm{pi}}$ is Relative creep coeffcient of each deformation and $\mathrm{t}$ is days.

Table 8 Relative creep coefficient of curvature for design

\begin{tabular}{cccccccccc}
\hline Specimen & $\mathrm{Ew}_{\mathrm{w}}$ & $\mathrm{Es}$ & $\mathrm{EIw}$ & $\mathrm{EIs}$ & $\mathrm{EIs} / \mathrm{EIw}$ & $\phi \mathrm{w}$ & $\alpha \mathrm{w}$ & $\alpha \mathrm{s}$ & $\mathrm{C}_{\mathrm{j}}$ \\
\hline $\mathrm{WO}$ & \multirow{2}{*}{6,500} & \multirow{2}{*}{20,500} & 98 & 0 & 0.00 & 2.00 & 0.50 & 1.00 & 2.00 \\
$\mathrm{HW} 3$ & $\mathrm{~N} / \mathrm{mm}^{2}$ & $\mathrm{~N} / \mathrm{mm}^{2}$ & 90 & 250 & 2.77 & 2.00 & 0.50 & 1.00 & 1.15 \\
$\mathrm{HW} 4$ & & & 86 & 392 & 4.56 & 2.00 & 0.50 & 1.00 & 1.10 \\
\hline
\end{tabular}

$\overline{\text { Ew,Es: Young's Modulus, EIw,EIs: Bending stiffness of timber and rebars, } \mathrm{kN}} \cdot \mathrm{m}^{2}$

幅の軸（中心）になる直線は，それらの接線（青の破線）の間の中 線 (一点鎖線) と見なせる。現時点では, 経過時間の進展に伴って 振幅が零に近づくと，それ以降は，振幅は目立たず，その中線に従 ってクリープは進行すると考えられる。中線は両接線の交点を通過 して両接線の傾きの平均值を傾きとする直線とする。

\section{3 測定期間と開始時期と終了時期}

前節の方法による接線と振幅の中心の直線を Fig.21 から Fig.23 中に示す。たわみと曲率のクリープ係数の振幅は接線に沿って収束 しており, 中線 (一点鎖線) で 50 年後を推測できると考えられる。 接線は 120 日以降, 寸なわち 4 月以降でのデー夕において変化が 反転する点を特定して, それらの回帰直線とした。接線を求めるた めに 2 点は必要なので, 初年度の IV 期 (6-9 月期) と次年度の IV 期を終えて, 変化傾向が反転する日を特定する必要があるため 10 月以降に一定の測定期間がないと判定できない。一般には一次クリ 一プの特性も把握したいので，少なくとも 12 月末から開始して，2 年間の測定期間が必要となると考えられる。この期間の考え方は, 荒武らが推奨している試験期間を，季節要因によるクリープの変動 量の収束性に基づいて裏付けたことになる。本試験体はラミナ構成 が対称な集成材であるが，鉄筋まわりの木部の吸湿と脱湿の影響を 受けてクリープの変動が大きいため, 荒武らが想定しているラミナ 構成が非対称な集成材で必要とする 2 年の測定期間に該当すると考 えられる。荒武ら ${ }^{17)}$ は 6 ケ月経過以降のデータに対して回帰直線 を求めているが，その回帰直線は，その期間のデータが等間隔で測 定され，期間が長くなれば一点鎖線の中線に収束する。季節性の変 動は 1 年周期で生じるので同法でクリープ係数を推定する場合，有 効な測定期間の始まりと終わりの時点の設定により影響を受ける場 合がある。本論の方法は中線で評価するため, その影響は生じない。

Fig.23(b)のせん断ひずみでは, HW3 は接線の間で振幅が収束し ている。HW4 も横軸の值が 2.8(631 日経過) までは同様に収束し ているが，それ以降，接線を越えて急増している。最大せん断応力 度は Table 6 で示したとおり，HW4 はせん断応力度が極めて大きい ためクリープ限界を越えて発散に向かっている可能性がある。

WO は最大振幅に対する接線はほぼ平行で，中線も接線にほぼ平 行になっている。横軸の值が零の時点は 1 日経過時点で， 0.2 の時 点は 1.5 日経過時点である。これ以降は一定の振幅で増加している。 この場合も中線によりクリープ調整係数を推測できると考えられる。 


\subsection{0 年後のクリープ調整係数の予測}

Table 7 に 6.2 節で述べた中線により算出された試験 I $の 50$ 年後 のクリープ調整係数を示す。たわみと曲率およびせん断ひずみにつ いて示す。HW3 と HW4 のせん断ひずみについては, 長期許容せん 断応力度を大きく上回っているので参考值と見な寸べきである。

Fig.21 から Fig.23 にピンクの曲線で試験 II の相対クリープ係数の 対数值の変化を挿入する。変動量の振幅が小さいため, クリープ係 数が収束する方向性は見られる。せん断ひずみは, 試験 I と同程度 の速度で増加している。

Fig.24(b) に示すように, 試験 II はまだ約 1 年半の測定期間で, 接線 2 を特定することが不可能である。接線 1 のみによる值を試験 I と同様に Table 7 の試験 II の欄に示す。この接線 1 によるクリー プ調整係数は, 安全側の值となるので参考にはなると考えられる。

たわみと曲率のクリープ調整係数は試験 $\mathrm{I}$ に対して極めて小さく なっている。2-WOの曲率のクリープ量も小さいので, 断定的なこ とは言えないが，2-WOが 1.22 となっているのに対して，2-HW3

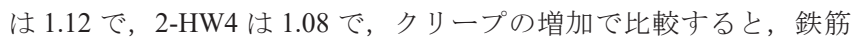
により約 36\%から 55\% に抑制されていることになる。

設計では, 鉄筋ラミナへの防水を施して, 集成材のクリープ調 整係数を使用環境に基づいて 2.0 か 3.0 に設定し， $\alpha_{\mathrm{s}}$ を 1.0 として 式 (6)により計算される值に安全率を考慮した值を曲率のクリープ 係数とすることが考えられる。集成材の曲率のクリープ調整係数を 2.0 とした場合の式 (6) による曲率のクリープ調整係数 $\mathrm{C}_{\phi}$ を計算し た結果を Table 8 に示す。ヤング係数は設計值を用いている。

同表右欄の $\mathrm{C}_{\phi}$ の值から明らかなように鉄筋ラミナへの防水を施 せば，極めて大きなクリープ抑制効果を期待できることになる。

as 1.0 とする式 (6) の妥当性は, 続報として投稿する高温環境 の長期載荷試験で鮮明に裏付けられることになる。その理由は高温 環境では集成材への水分の浸透が生じないで鉄筋まわりの木部に水 分が浸透しないからである。詳細は続報で述べることにする。

せん断ひずみのクリープ調整係数は, 一般の集成材の係数に従 うことを想定しているが, 研究例が極めて少ない。参考になるの は, Table 7 に示寸試験 I と試験 II の WO の実験值で 1.94( コーティ ング無し)または 1.58( コーティング有り)の值である。これらの 試験体ではせん断応力度が長期許容応力度を下回っているためであ る。設計では安全側でコーティングを施さない場合の值 (1.94) とす べきである。この值は大橋らが報告している I ジョイストの実験值 (1.92-1.99 $)^{23)}$ と同程度であり，一定の信頼性はあると考えられる。

\section{7. クリープ進行中のたわみ剛性}

長期期間のクリープによりたわみ剛性が低下寸ると，人の動作や 機器の振動による振動障害が生じる心配がある。試験 I の長期荷重 を導入する際の弾性のたわみ剛性と, 試験 I の中断の除荷時 (2019 年 5 月 15 日）の剛性を比較することにより, たわみ剛性の変化を 確認することができる。前頁の Fig. 25 にたわみ，曲率および，せ ん断ひずみを比較して示す。細線が初期の長期導入時である。太線 が試験 I の中断時である。試験体の線の色は同じである。長期載荷 開始から約 2 年 6 ケ月が経過した時点である。試験 I の長期荷重の 導入時の剛性に合わせるように水平移動させた関係を点線で示す。

全ての試験体で試験開始前と試験終了後ではたわみと曲率の除荷

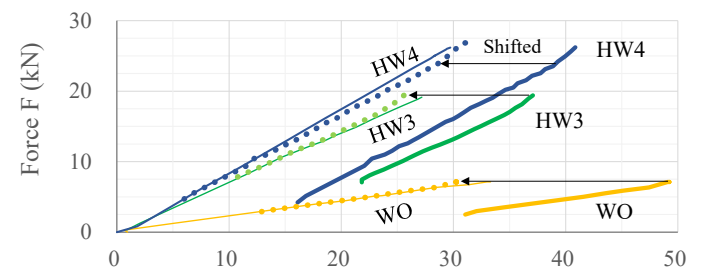

(a) Deflection (mm)

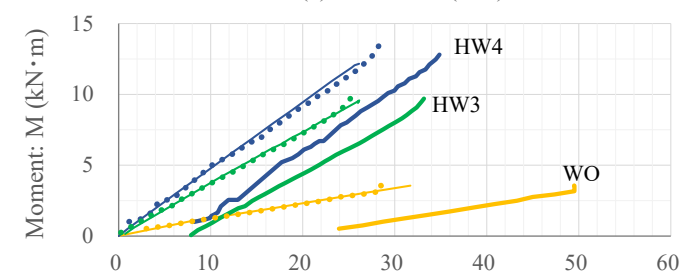

(b) Curvature ( $\left.\times 10^{-6} 1 / \mathrm{mm}\right)$

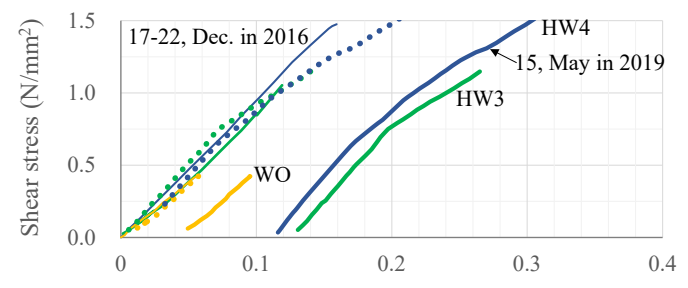

(c) Shear strain (\%)

Fig. 25 Comparison of stiffnesses before and after long-term loading test

時の剛性はほとんど変わらないことが分かる。木材の梁にはクリー プによる塑性変形が生じても，その時点での荷重変動に対する接線 剛性はほとんど低下しない特性があると考えられる。せん断ひずみ については，HW3 と HW4 はせん断応力が長期許容応力度を上回っ ているため，除荷時に材料非線形の特性が生じたと考えられる。こ のせん断ひずみの非線形性を除くと, 巨視的にはクリープ進行中ま たは収束後の, 人の動作や機器の振動よる梁の振動性能は, 設計時 に想定した性能とほぼ同じと考えられる。

\section{8. まとめ}

木質ハイブリッド部材の梁のクリープ特性に関する既往の研究を 調查し, 現時点で明らかになっている事項をまとめ, 鉄筋集成材の クリープの曲率成分の評価式を示し, 実施した梁の長期載荷試験（ 試験 I と II) の結果に適用し, 鉄筋集成材のラミナ構成の問題点と 対策について述べた。さらに, 季節性の変動を伴う実験データから クリープ係数を推定する方法を提案して 50 年後のクリープ係数を 示して設計での対応について述べた。またクリープが進行している 間のたわみ剛性も明らかにした。以下に結果をまとめる。

(1) 鉄筋を接着するラミナ（鉄筋ラミナ）を最外層にする構成とす ると，我が国では 7 月から 9 月の期間の湿度の上昇に伴い，鉄 筋まわりの木部に水分が浸透し, その部分のせん断剛性が低下 して鉄筋の梁の曲げ剛性への寄与効果が低下する。この基本対 策は，鉄筋ラミナを最外層から内側の第 2 層目以降に接着寸る 構成とすることである。さらに集成後，鉄筋ラミナの側面に木 部の被りを確保または防水用の塗料を塗布するか, また耐火被 覆材も兼㸚るコーティング材で覆うなどの方法が考えられる。

(2) 鉄筋ラミナへの水分の浸透が防止されると, 鉄筋により梁のク リープの曲率成分の増加を抑制でき, 曲率の相対クリープ係数 
は式 (6) で $\alpha_{\mathrm{s}}$ を 1.0 として概ね評価できる。設計で集成材のク リープ調整係数を 2.0 とする場合，本実験の鉄筋集成材の試験 体の断面では, 1.15 または 1.10 にまで抑制できる可能性があり, 鉄筋のクリープの曲げ変形成分の抑制効果を期待できる。

(3) クリープが季節的な要因により大きく変動しながら増大寸る場 合のクリープ調整係数の求め方を提案した。

(4) クリープ進行時のたわみ剛性は弾性時の剛性とほぼ同じで, ク リープたわみが進行した後でも，たわみが制限範囲以下であれ ば，鉄筋の有無に関係なく，クリープの進行に伴う振動障害が 生じる可能性は極めて低い。

上記の (2) と (4) については，続報として投稿する高温環境の鉄 筋集成材梁の長期載荷試験で鮮明に裏付けられることになる。

謝辞

試験 I は「平成 28 年度林野庁委託事業」（委員長：五十田 博 教 授 )として行った。試験 I と II は本学院生清藤彩さんと学部生 塩 満祐真氏の研究として実施した。関係各位に深甚なる謝意を表する。

\section{参考文献}

1)S. Shioya: Hybrid timber-steel bar glulam and its building system, JTCCM JOURNAL Vol. 52, 2-7, 2016.8 (in Japanese)

2)S. Shioya, T. Hira: Experimental investigation of bending behavior of hybrid timber beams reinforced using steel bars subjected to cycle loading, AIJ Journal of Technology and Design, Vol. 22, No. 50, pp. 73-76, 2016.2 (in Japanese)

3) S. Shioya: Bending behavior and design method for hybrid timber-steel bar glulam beam subjected to short-term loading, Journal of Structural and Construction Engineering (Transactions of AIJ), Vol. 84, No. 756, pp.247- 256, 2019.2

4)S. Shioya, Y. Shimizu, H. Shioji: Duration of load factor for hybrid timber-steel bar, Journal of Structural and Construction Engineering (Transactions of AIJ), Vol. 52, No. 756, pp.257-266, 2019.2 (in Japanese)

5)S. Shioya, N. Matsuoka: Internal stress of steel bar-timber hybrid glulam beam derived from temperature and moisture content variation, Journal of Structural and Construction Engineering (Transactions of AIJ), Vol. 85, No. 777, pp.1469-1478, 2020.11 (in Japanese)

6)S. Shioya, Y. Iju, T. Ohta, T. Haruguchi: Bending elastio-plastic behavior of hybrid glulam timber column using steel bars and epoxy resin adhesive (Part1): a lateral loading experiment of columns with rectangular section, Journal of Structural and Construction Engineering (Transactions of AIJ), Vol. 86, No. 779, pp.107-116, 2021.1 (in Japanese)

7)Granholm, H.: Armerat Tra (Reinforced timber), Chalmers Tekniska Hogskolas Handlingar, No.154, pp. 68-76, Gothenburg, Sweden, 1954

8)N. Plevris and T. Triantafillou: Creep behavior of FRP-reinforced wood members, Journal of Structural Engineering, vol. 121, No. 2, pp. 174-186, 1995

9)W. G. Davids, H. J. Dagher, and J. M. Breton: Modeling creep deformations of FRP-reinforced glulam beams, Wood Fiber Sci., Vol. 32, No. 4, pp. 426-441, 2000.

10)J.R. Gilfillan, S.G. Gilbert and G.R.H. Patrick: The use of composite in enhancing the structure behavior of timber beams, Journal of Reinforced Plastics and Composites, p.p. 1373-1384, Vol, No. 15, 2003

11) R. Kliger, M. Al-Emrani, M. Johansson, R. Crocetti : Strengthening timber with CFRP or steel plates-Short and long-term performance, Proceedings of 10th World Conference Timber Engineering, WCTE2008, Miyazaki, Japan, 2008

12)M.Yahyaei-Moayyed and F. Taheri: Experimental and computational investigations into creep response of AFRP reinforced timber beams, Compos. Struct., Vol. 93, No. 2,pp.616-628, 2011

13)Conan O'Ceallaigh, Karol Sikora, et.al.; Viscoelastic creep in reinforced glulam, Proceedings of World Conference on Timber Engineering, WCTE 2016, CD, Wien City, Austria, 2016

14)Conan O'Ceallaigh, Karol Sikora, et.al.; Mechano-sorptive creep in reinforced glulam, Proceedings of the World Conference on Timber Engineering, WCTE 2018, CD, Seoul City, Republic of Korea, 2018

15)S. Goto, M. Tokuda: Creep of hybrid composite timber beam, The 47th Annual Meeting of the JWRS, No.4, pp. 915-196, 1997 (in Japanese)

16)S. Nakajima, et al.: Creep performance of hybrid timber beams, The 8th World
Conference on Timber Engineering, WCTE 2004, Lahti, Finland, 2004

17)Shiro Aratake, Hideki Morita, Takanori Arima: Bending creep of glued laminated timber (glulam) using sugi (Cryptomeria japonica) laminae with extremely low Young's modulus for the inner layers, J. Wood Sci (2011) 57, pp.267-275, The Japan Wood Research Society 2011

18)Felipe Riola Parada, Wolfgang Winter, Kamyar Tavoussi: Long-term testing of timber-steel hybrid beams, Proceedings of World Conference on Timber Engineering, WCTE 2016, Wien City, Austria, 2016

19)T. Hira, S. Shioya, T.Koga: Timber Frame Reinforced by Reinforcing Steel Bar Part III, Creep Test of Reinforced Timber Beam, AIJ Kyushu Chapter Architectural Research Meeting, No.51, pp. 593-596, 2012. 3 (in Japanese) 比良朋香, 塩屋晋一, 古賀武司 : 高剛性・高耐力・高エネルギー吸収型の立 体木質ラーメン骨組の開発, その 3. 鉄筋で曲げ補強した梁のクリープ試験, 日本建築学会研究報告, 九州支部, 構造系, 51 号,pp.593-596, 2012.3

20)S. Kiyotou, S. Shioya: Long-term testing of timber-steel bar hybrid beams, Proceedings of the World Conference on Timber Engineering, WCTE 2018, CD, Seoul City, Republic of Korea

21)T.Arima:Timber saves health and environment, p.66,Sancho, 1998.8 (in Japanese) 有馬孝禮 : 木材は健康と環境を守る,p.66, 産調出版株式会社, 1998.8

22)S. Kiyotou, S. Shioya, T. Izaki: Long-term testing of timber-steel bar hybrid beams, Part 2. Numerical analysis on phenomenon of shear creep boosting bending creep, AIJ Kyushu Chapter Architectural Research Meeting, No.58, pp.537-540, 2019. 3 (in Japanese)

清藤 彩, 塩屋晋一, 井崎 丈: 長期載荷を受ける鉄筋集成材梁の曲げクリ ープ特性に関する研究, その 2. せん断クリープが曲げクリープを促進さ せる現象の解析, 日本建築学会研究報告, 九州支部, 構造系, 58 号, pp.537$540,2019.3$

23)Y. Ohashi, et al.: Mechanical properties of wooden I-beams with plantation timber materials in Hokkaido III, Shear creep property, Journal of the Japan Wood Research Society, Vol.55, No.4, pp.217-225, 2009 (in Japanese)

注

注 1) 鉄筋集成材では鉄筋により曲げ変形を抑制するため, 部材の全変形に 占めるせん断変形の割合は 20-30\% となり，ウェッブの集成材のせん断 変形のクリープの解明も重要になる。現状ではせん断クリープについ ては文献 23) があるのみで今後の課題である。設計では当面, せん断 変形成分のクリープ係数は安全側で設定する必要がある。

注 2) 鉄筋集成材の梁では, 弾性変形では中央たわみに対してせん断変形が 占める割合は 10-25\% を想定している。本試験体の計算值では, HW3 は 7.4\%で, HW4 は 10.3\%であつた。

注 3) 鉄筋集成材の許容曲げモーメントは鉄筋の許容応力度または集成材の 曲げ縁の許容応力度の小さい方で決定する。実験計画の段階では, 前 年度に実施した文献 4) の集成材の梁の短期載荷試験の集成材 (フィン ガージョイント縦継ぎあり)の曲げ強度の実験值 $38.5 \mathrm{~N} / \mathrm{mm}^{2}$ を想定し た。本試験体は手配のミスにより縦次無しのラミナで構成されて，梁 の短期載荷試験の結果 ${ }^{3)}$, 集成材試験体 WO $の 3$ 体の曲げ強度の平均値 は， $53.2 \mathrm{~N} / \mathrm{mm}^{2}$ となった。この值に基づいて，長期許容曲げモーメン 卜を計算すると，鉄筋集成材梁の鉄筋の応力が $313 \mathrm{~N} / \mathrm{mm}^{2}$ となり，異 形鉄筋の長期の許容応力度 $215 \mathrm{~N} / \mathrm{mm}^{2}$ を大きく上回ることになった。 実際の鉄筋集成材は大断面でフィンガージョイントを設けたラミナを 用いることになるため, 当初の想定した $38.5 \mathrm{~N} / \mathrm{mm}^{2}$ を集成材の曲げ強 度と想定して梁のスパン中央の曲げモーメントが長期の許容曲げモー メントになる荷重を，それぞれの梁に作用させた。平面保持の仮定に 基づいて計算している。この場合，鉄筋の応力度は，計算上， $208 \mathrm{~N} /$ $\mathrm{mm}^{2}$ となる。材料試験による鉄筋 D13 の降伏強度は $371 \mathrm{~N} / \mathrm{mm}^{2}$ で, 鉄 筋 D16 は $355 \mathrm{~N} / \mathrm{mm}^{2}$ であり, SD345の規格降伏応力度以上であった。 $\mathrm{SD} 345$ の鉄筋の長期の許容応力度は $215 \mathrm{~N} / \mathrm{mm}^{2}$ であり，今回，設定し た長期載荷時の曲げモーメントは，SD345 の鉄筋を用いた場合の鉄筋 集成材梁の長期の許容曲げモーメントに相当する。結果としては鉄筋 集成材の設計で長期の許容曲げモーメントに相当する荷重を作用させ たことになる。短期の許容曲げモーメントに対する長期許容曲げモー メントの比は，鉄筋で許容曲げモーメントが決まるので $2 / 3$ となる。

注 4) 鉄筋集成材梁内で集成材部分で曲げのクリープが進行すると，平面保 持の仮定が成立している状態であれば，鉄筋による曲げ剛性の寄与率 がさらに増大して，集成材の曲げクリープが鉄筋集成材梁の曲げクリ ープに及ぼす影響は低下寸ることになる。このことから本文では $30 \%$ 以下や $23 \%$ 以下などと表現している。 


\title{
CREEP BEHAVIOR OF HYBRID REBAR-GLULAM TIMBER BEAM UNDER LONG-TERM LOADING
}

\author{
ShinichiSHIOYA ${ }^{* 1}$, Kanta FUKUDOME ${ }^{* 2}$ and Nao MATSUOKA *3 \\ ${ }^{11}$ Prof., Kagoshima University, Dr.Eng. \\ ${ }^{2}$ Takenaka Corporation, M.E. \\ ${ }^{* 3}$ Graduate School, Kagoshima University, Master Course Student
}

Recently, from view - point of Global Environment, timber, i.e., one of nature-cycle materials, is being tried to be utilized as structural members of large timber buildings in Europe and North America.

A representative timber of the members is Cross-laminated timber (CLT), however, CLT structural system very often restricts planning of building because of CLT being plate member. High-stiffness-strength-timber slender beam and column are significantly desired.

This study focuses a hybrid glulam timber beam with steel deformed bar (rebar) and Epoxy resin adhesive.

The aim of this study is to clarify mechanism of suppressing bending creep of the hybrid beam by rebars and to develop method of estimating its relative creep coefficient in design. This paper reported creep behavior of hybrid glulam timber beams with a small size under 4-year term loading and additional coated beams under 1.5-year term loading. The coated beam specimens were prepared in order to investigate adverse effects of moisture on shear stiffness of wood around the rebars. The result and discussion of the two experiments are summarized as follows:

( i ) Creep of curvature of the hybrid beam rapidly boosted against prediction based on assumption of Navier hypothesis, during same term in every year when humidity increases in Japan, i.e., July-September, as Fig.11.

(ii ) The boost results from position of rebar-embedded lamina in the beam section because moisture in air around beam percolates surface of its timber and decreases shear stiffness of wood part around rebars. One of basic ways to protect the decrease is to arrange the rebar-embedded lamina as the second layer from outer layer because adhesive layers between the outer layer and the second, as seen in Fig. 20, prevent the moisture from percolating the second layer, i.e., rebar lamina.

(iii) This problem may occur in the small-sized beam, however, the real full-sized hybrid beam can readily prevent it in some ways as shown in Fig.20(b), (c), by using waterproof coating, burning marginal later, or refractory coating.

(iv) The protected hybrid beam is estimated to significantly suppress its bending creep by rebars, as Relative creep coefficient $\mathrm{C}_{\phi}$ of curvature in 50-year for design listed in Table 8.

( v ) Deflection-stiffness of timber beam and hybrid beam rarely deteriorated during creeping, as Fig.25.

(vi) A prediction method for relative creep fluctuating intensely owing to seasonal influence was proposed by using two - tangent lines on logarithmic chart, as Fig.21, Fig.22, and Fig.23. 